Review

\title{
Review on greenhouse gas emissions from pig houses: Production of carbon dioxide, methane and nitrous oxide by animals and manure
}

\author{
F.-X. Philippe*, B. Nicks \\ Department of Animal Productions, Faculty of Veterinary Medicine, University of Liège, Boulevard de Colonster 20, B43, Liège 4000, Belgium
}

\section{A R T I C L E I N F O}

\section{Article history:}

Received 31 January 2014

Received in revised form 6 August 2014

Accepted 12 August 2014

Available online $\mathrm{xxx}$

\section{Keywords:}

Carbon dioxide

Methane

Nitrous oxide

Pig

Manure

\begin{abstract}
A B S T R A C T
The environmental impacts of livestock production are attracting increasing attention, especially the emission of greenhouse gases (GHGs). Currently, pork is the most widely consumed meat product in the world, and its production is expected to grow in the next few decades. This paper deals with the production of carbon dioxide $\left(\mathrm{CO}_{2}\right)$, methane $\left(\mathrm{CH}_{4}\right)$ and nitrous oxide $\left(\mathrm{N}_{2} \mathrm{O}\right)$ by animals and by manure from pig buildings, with a focus on the influence of rearing techniques and nutrition. GHG emissions in piggeries originate from animals through $\mathrm{CO}_{2}$ exhalation and $\mathrm{CH}_{4}$ enteric fermentation, and from manure through the release of $\mathrm{CO}_{2}, \mathrm{CH}_{4}$ and $\mathrm{N}_{2} \mathrm{O}$. The level of the $\mathrm{CO}_{2}$ exhalation $\left(\mathrm{E}-\mathrm{CO}_{2}\right.$, pig $)$ depends on the physiological stage, the body weight (BW), the production level and the feed intake of the animals concerned. Enteric $\mathrm{CH}_{4}\left(\mathrm{E}-\mathrm{CH}_{4}\right.$, pig $)$ is principally related to dietary fibre intake and the fermentative capacity of the pig's hindgut. Based on a review of the literature, the following equations are proposed in order to estimate $\mathrm{E}-\mathrm{CO}_{2}$, pig (in kg day ${ }^{-1}$ ) and $\mathrm{E}-\mathrm{CH}_{4, \mathrm{pig}}$ (ing day ${ }^{-1}$ ) for fattening pigs: $\mathrm{E}-\mathrm{CO}_{2}$, pig $=0.136 \times \mathrm{BW}^{0.573} ; \mathrm{E}^{-\mathrm{CH}_{4} \text {, pig }}=0.012 \times \mathrm{dRes}$; with $\mathrm{BW}$ (in $\mathrm{kg}$ ) and $\mathrm{dRes}$ for digestible residues (in $\mathrm{g}$ day $^{-1}$ ). Numerous pathways are responsible for GHG production in manure. In addition, the microbial, physical and chemical properties of manure interact and modulate the level of emissions. Influencing factors for removal systems for both liquid and solid fractions of manure have been investigated. A large range of parameters showing an impact on the level of GHG production from pig houses has been reported. However, few of these can be considered unquestionably as GHG mitigation techniques because some strategies have shown contradictory effects depending on the gas, the circumstances and the study. Nevertheless, frequent manure removal seems to be an efficient means to reduce concurrently $\mathrm{CO}_{2^{-}}, \mathrm{CH}_{4^{-}}$ and $\mathrm{N}_{2} \mathrm{O}$-emissions from pig buildings for both slatted and bedded floor systems. Manure removal operations may be associated with specific storage conditions and efficient treatment in order to further reduce emissions. Several feeding strategies have been tested to decrease GHG emissions but they seem to be ineffective in reducing emissions both significantly and durably. In general, good management practices that enhance zootechnical performance will have beneficial consequences on GHG emission intensity. Taking into account the results described in the literature regarding $\mathrm{CO}_{2^{-}}, \mathrm{CH}_{4^{-}}$and $\mathrm{N}_{2} \mathrm{O}-$ production from animals and manure in pig houses, we estimate total GHG emissions to $448.3 \mathrm{~kg}$ $\mathrm{CO}_{2}$ equiv. per slaughter pig produced or $4.87 \mathrm{~kg} \mathrm{CO}$ equiv. per $\mathrm{kg}$ carcass. The fattening period accounts for more than $70 \%$ of total emissions, while the gestation, lactation and weaning periods each contribute to about $10 \%$ of total emissions. Emissions of $\mathrm{CO}_{2}, \mathrm{CH}_{4}$ and $\mathrm{N}_{2} \mathrm{O}$ contribute to 81,17 and $2 \%$ of total emissions from pig buildings, representing 3.87, 0.83 and $0.11 \mathrm{~kg} \mathrm{CO}$ equiv. per $\mathrm{kg}$ carcass, respectively.
\end{abstract} (C) 2014 Elsevier B.V. All rights reserved.

\section{Contents}

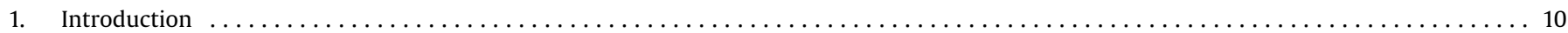

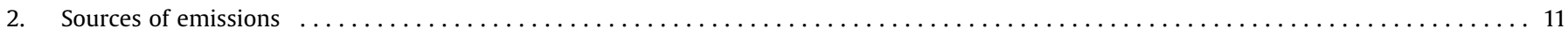

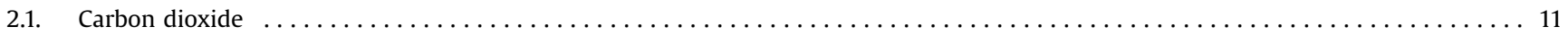

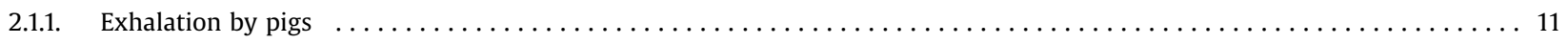

\footnotetext{
* Corresponding author. Tel.: +32 4366 4142; fax: +32 43664122.

E-mail address: fxphilippe@ulg.ac.be (F. -X. Philippe).
} 


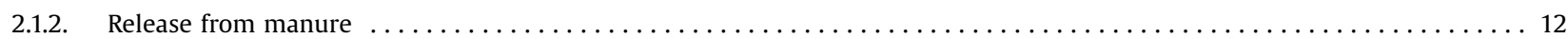

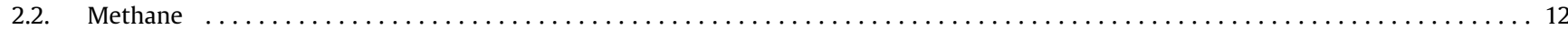

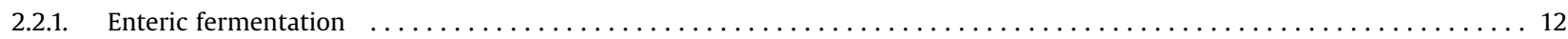

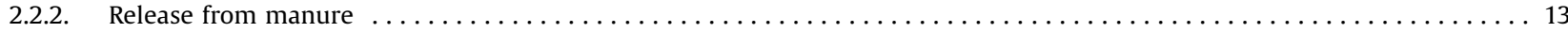

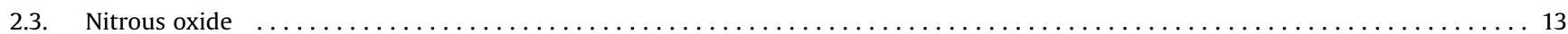

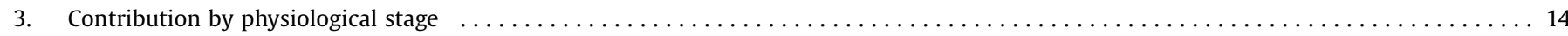

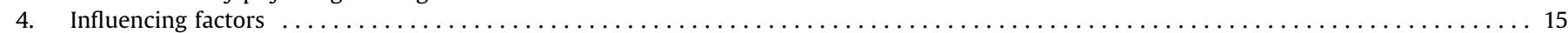

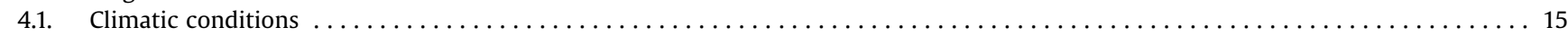

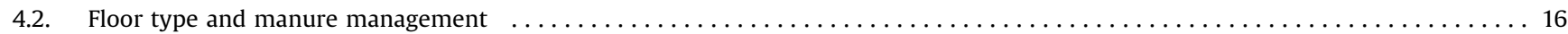

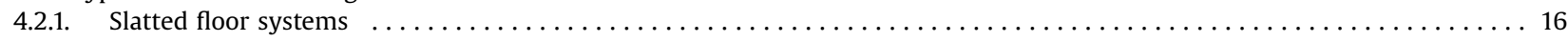

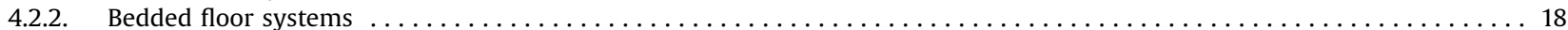

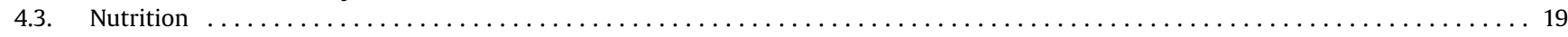

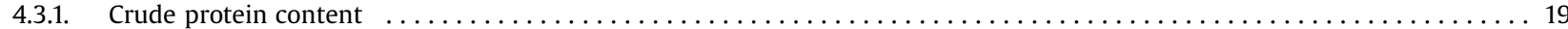

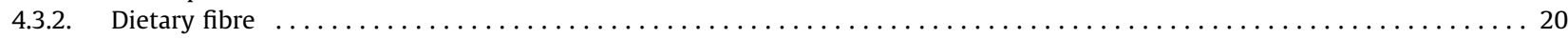

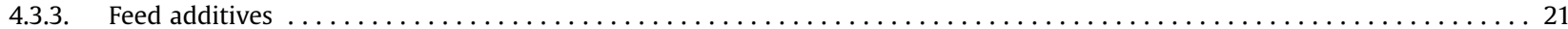

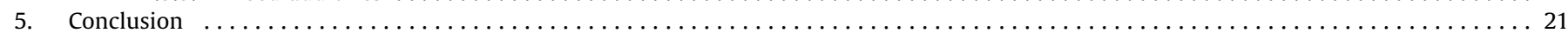

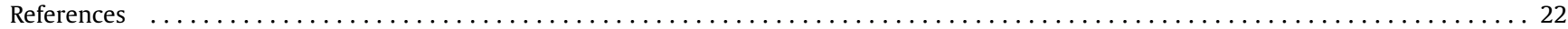

\section{Introduction}

Globally, livestock production accounts for $18 \%$ of anthropogenic emissions of greenhouse gases (GHGs) (Steinfeld et al., 2006). Pork is the most widely consumed meat product in the world, and pig production is the second contributor of GHG emissions from livestock sector, with about $13 \%$ of total emissions being related to livestock (Tables 1 and 2; FAO, 2011). By 2050, worldwide pork consumption is expected to increase by almost $40 \%$ (FAO, 2011). Most of that increase in consumption will occur in developing countries, owing to demographic growth, changes in food preferences and better access to food due to the intensification of livestock systems close to growing urban populations (FAO, 2011). Presently, industrial farm animal production systems account for over half of pork production, and developing countries contribute to about half of this industrial production (Steinfield et al., 2006). In the future, these shares are expected to grow dramatically. Therefore, the environmental impact of industrial pig production represents a crucial issue for consideration in ensuring sustainability in meat production. Moreover, reducing GHG emissions would mitigate the adverse effects of GHGs on global climate change (increased temperature, higher sea level, drought, soil erosion and loss of global crop productivity) (IPCC, 2007).

Within this context, this paper aims to study the factors that influence the production levels of carbon dioxide $\left(\mathrm{CO}_{2}\right)$, methane $\left(\mathrm{CH}_{4}\right)$ and nitrous oxide $\left(\mathrm{N}_{2} \mathrm{O}\right)$ by animals and manure at pig house level. Emissions associated with feed production, land use and land use change, energy consumption, manure spreading, transportation and food processing are not included in this discussion. Emissions associated with outside manure storage and manure treatments are also outside the scope of this review. These issues will, nevertheless, be briefly touched upon due to the link with emissions released from pig buildings. Direct $\mathrm{CO}_{2}$ emissions from animals and from manure are usually excluded from GHG assessment because it is assumed that they are compensated by $\mathrm{CO}_{2}$ consumption through the photosynthesis of plants used as feed. Consequently, $\mathrm{CO}_{2}$ production by animals and by manure is rarely addressed in the literature. However, these $\mathrm{CO}_{2}$ emissions at house level are not negligible and may differ from one rearing system to another (Philippe et al., 2007a,b). Moreover, since the synthesis pathways of carbon compounds are interlinked, it seems relevant to consider $\mathrm{CO}_{2}$ and $\mathrm{CH}_{4}$ emissions comprehensively. Indeed, a significant reduction in one gas could be compensated by an increase in another. Thus, the choice has been made to include $\mathrm{CO}_{2}$ emissions in this paper in order to avoid any errors of judgement in assessing the environmental effect of a particular type of GHG mitigation technique.

The paper is organized as follows. Firstly, it describes the processes that are responsible for the production of $\mathrm{CO}_{2}, \mathrm{CH}_{4}$ and $\mathrm{N}_{2} \mathrm{O}$ by animals and by manure at pig house level. Secondly, emission factors reported in the literature are reviewed according to the physiological stages of pig development, and an overall emission factor is proposed for the complete pig production process. Finally, the effects of pig rearing conditions (including dietary factors) on emissions are studied and some mitigation techniques are described.

\section{Sources of emissions}

\subsection{Carbon dioxide}

The emissions of $\mathrm{CO}_{2}$ from pig houses come from two sources: exhalation by pigs and release from manure.

\subsubsection{Exhalation by pigs}

$\mathrm{CO}_{2}$ production during respiration is related to the respiratory quotient, defined as the ratio between the volume of $\mathrm{CO}_{2}$ production and the volume of oxygen consumption. In practice,

Table 1

Projected human population (in billion people) and global meat consumption (in million tons) from 2010 to 2050. Source: adapted from FAO, 2011.

\begin{tabular}{|c|c|c|c|c|c|}
\hline & 2010 & 2020 & 2030 & 2050 & Growth $2010-2050$ \\
\hline Human population & 6.91 & 7.67 & 8.31 & 9.15 & $+32 \%$ \\
\hline \multicolumn{6}{|l|}{ Meat consumption } \\
\hline Pig meat & $102.3(38 \%)$ & $115.3(36 \%)$ & 129.9 (34\%) & $140.7(30 \%)$ & $+38 \%$ \\
\hline Poultry meat & $85.9(32 \%)$ & $111.0(35 \%)$ & $143.5(38 \%)$ & $193.3(42 \%)$ & $+125 \%$ \\
\hline Bovine meat & $67.3(25 \%)$ & 77.3 (24\%) & $88.9(23 \%)$ & $106.3(23 \%)$ & $+58 \%$ \\
\hline Sheep/goat meat & $13.2(5 \%)$ & $15.7(5 \%)$ & $18.5(5 \%)$ & $23.5(5 \%)$ & $+78 \%$ \\
\hline All meat & $268.7(100 \%)$ & $319.3(100 \%)$ & $380.8(100 \%)$ & $463.8(100 \%)$ & $+73 \%$ \\
\hline
\end{tabular}


Table 2

Contribution of livestock species to global greenhouse gas emissions.

Source: adapted from Steinfeld et al., 2006; FAO, 2013a,b.

\begin{tabular}{|c|c|c|c|c|}
\hline \multirow[t]{2}{*}{ Species } & \multicolumn{4}{|c|}{ Greenhouse gas emissions (million tons $\mathrm{CO}_{2}$ equiv. year ${ }^{-1}$ ) } \\
\hline & $\mathrm{CO}_{2}$ emissions & $\mathrm{CH}_{4}$ emissions & $\mathrm{N}_{2} \mathrm{O}$ emissions & Total emissions \\
\hline Cattle & $1166.2(61 \%)$ & $2072.8(81 \%)$ & $661.6(60 \%)$ & $3900.6(70 \%)$ \\
\hline Small ruminants & $69.9(4 \%)$ & $244.5(10 \%)$ & $202.6(18 \%)$ & $517.0(9 \%)$ \\
\hline Pigs & $338.9(18 \%)$ & $237.3(9 \%)$ & $131.1(12 \%)$ & $707.3(13 \%)$ \\
\hline Poultry & $332.2(17 \%)$ & - & $107.3(10 \%)$ & $439.5(8 \%)$ \\
\hline Total & $1907.2(100 \%)$ & $2554.5(100 \%)$ & $1102.6(100 \%)$ & $5564.3(100 \%)$ \\
\hline
\end{tabular}

$\mathrm{CO}_{2}$ equiv.: emissions of $\mathrm{CO}_{2}$-equivalents, including $\mathrm{CO}_{2}, \mathrm{CH}_{4}$ and $\mathrm{N}_{2} \mathrm{O}$, taking into account the global warming potential of 25 and 298 for $\mathrm{CH}_{4}$ and $\mathrm{N}_{2} \mathrm{O}$, respectively.

the respiratory quotients reported in the literature are around 1.10 for growing pigs, around 1.00 for piglets and around 0.90 for reproductive sows (Moehn et al., 2004; Pedersen et al., 2008; Atakora et al., 2011b). $\mathrm{CO}_{2}$ exhalation can also be derived from animal heat production (HP), which corresponds to the energy used for maintenance, production (growth or milk production) and thermoregulation (Noblet et al., 1989). The International Commission of Agricultural Engineering (CIGR, 2002) stated that HP should be estimated by taking into account the pig's body weight (BW), the production level and the feed energy intake. The production of respiratory $\mathrm{CO}_{2-}$ can be derived from these models, and corresponds to $2.23,3.68,0.88$ and $1.70 \mathrm{~kg} \mathrm{CO}_{2}$ head $^{-1}$ day $^{-1}$ for gestating sows, lactating sows, weaned piglets and fattening pigs, respectively (CIGR, 2002). Other experiments have been carried out to measure or estimate $\mathrm{CO}_{2}$ exhalation from practical parameters. Models developed for fattening pigs are presented in Table 3 and illustrated in Fig. 1. In cases of a lack of data, models were simplified to express the $\mathrm{CO}_{2}$ exhalation function of $\mathrm{BW}$, according to data obtained by Aubry et al. (2004). An aggregation of the models reported in Table 3 gives the following equation proposed to predict $\mathrm{CO}_{2}$ exhalation $\left(\mathrm{E}-\mathrm{CO}_{2}\right.$, pig, in $\mathrm{kg} \mathrm{CO}_{2}$ day $\left.^{-1}\right)$ for pigs of $20-120 \mathrm{~kg}$ BW (Fig. $1 ; R^{2}=0.91$ ):

$\mathrm{E}-\mathrm{CO}_{2, \text { pig }}=0.136 \mathrm{BW}^{0.573}$

Thus, respiratory $\mathrm{CO}_{2}$ production can be estimated to about $1.55 \mathrm{~kg} \mathrm{day}^{-1}$ for a pig of $70 \mathrm{~kg} \mathrm{BW}$.

\subsubsection{Release from manure}

For many years, levels of $\mathrm{CO}_{2}$ emissions from manure were believed to be negligible (Anderson et al., 1987; van 't Klooster and Heitlager, 1994). According to some recent research, the levels of $\mathrm{CO}_{2}$ released from manure have been estimated to be $4-5 \%$ of the $\mathrm{CO}_{2}$ exhaled by animals (CIGR, 2002; de Sousa and Pedersen, 2004; Dong et al., 2007). However, some authors have reported $\mathrm{CO}_{2}$ release accounting for $10-30 \%$ of respiratory production (Jeppsson, 2000, 2002; Philippe et al., 2007a,b; Pedersen et al., 2008; Philippe et al., 2012a). During an experiment carried out in a commercial fattening unit, emissions from manure were evaluated to be at around $40 \%$ of the tranquil $\mathrm{CO}_{2}$ exhalation rate (Ni et al., 1999b). The production of $\mathrm{CO}_{2}$ from manure certainly needs to be taken into account, even though it is not the main source of $\mathrm{CO}_{2}$ in pig houses.

In manure, $\mathrm{CO}_{2}$ originates from three sources: (1) the rapid hydrolysis of urea into $\mathrm{NH}_{3}$ and $\mathrm{CO}_{2}$ catalysed by the enzyme urease; (2) the anaerobic fermentation of organic matter into intermediate volatile fatty acids (VFAs), $\mathrm{CH}_{4}$ and $\mathrm{CO}_{2}$; (3) the aerobic degradation of organic matter (Jeppsson, 2000; Moller et al., 2004; Wolter et al., 2004). For liquid manure, anaerobic processes have been frequently considered as the main source of $\mathrm{CO}_{2}$ (Ni et al., 1999b). However, this conclusion is contradictory to the results of Moller et al. (2004), who observed under laboratory conditions that aerobic and anaerobic processes are of almost equal importance at a temperature of $20^{\circ} \mathrm{C}$, while a lower temperature $\left(15^{\circ} \mathrm{C}\right)$ favoured the aerobic processes. Moreover, crust formation at the surface of the slurry can also lead to $\mathrm{CH}_{4}$ oxidation into $\mathrm{CO}_{2}$ during the passage through the porous areas of the crust.

For solid manure, the principal origin of $\mathrm{CO}_{2}$ is aerobic production, the so-called composting process, performed by a mesophilic/thermophilic microbial community that converts degradable organic matter (Hellmann et al., 1997; Wolter et al., 2004). The composting process is influenced by several factors, such as temperature, moisture content, carbon/nitrogen ratio, degradability of carbon compounds, $\mathrm{pH}$ level and the physical structure of the organic material (Andersson, 1996; Jeppsson, 2000; Paillat et al., 2005).

\subsection{Methane}

Methane originates from the anaerobic degradation of organic matter performed by bacteria in the digestive tract of the pigs and in the manure.

\subsubsection{Enteric fermentation}

The level of enteric $\mathrm{CH}_{4}$ production is mainly determined by the fibre content of the diet and the fermentative capacity of the pig's hindgut. Thus, increased levels of dietary fibre are associated with increased $\mathrm{CH}_{4}$ production, while fermentative capacity depends on the physiological stage of the pigs, with typically higher $\mathrm{CH}_{4}$ production for adult pigs (Le Goff et al., 2002a).

Table 3

Equations proposed to estimate $\mathrm{CO}_{2}$ exhalation by fattening pigs $\left(\mathrm{E}-\mathrm{CO}_{2}\right.$, pig, in $\left.\mathrm{kg} \mathrm{day}^{-1}\right)$ according to body weight (BW, in $\mathrm{kg}$ ).

\begin{tabular}{|c|c|c|}
\hline References & Equations & Methodology \\
\hline Müller and Schneider (1985) & $\mathrm{E}-\mathrm{CO}_{2, \mathrm{pig}}=0.114 \mathrm{BW}^{0.588}$ & Pigs in metabolic crates (from 20 to $110 \mathrm{~kg}$ ) \\
\hline Feddes and DeShazer (1988) & $\mathrm{E}-\mathrm{CO}_{2, \text { pig }}=0.136 \mathrm{BW}^{0.549}$ & Data derived from feed intakes \\
\hline van 't Klooster and Heitlager (1994) & $\mathrm{E}-\mathrm{CO}_{2, \text { pig }}=2.88 \times 10^{-2} \times \mathrm{BW}^{0.75}+8.29 \times 10^{-2} \times \mathrm{BW}^{0.549}$ & Data derived from feed intakes \\
\hline Ni et al. (1999a) & $\mathrm{E}-\mathrm{CO}_{2, \mathrm{pig}}=0.224 \mathrm{BW}^{0.46}$ & Field measurements in a commercial fattening pig house \\
\hline Brown-Brandl et al. (2004) & $\mathrm{E}-\mathrm{CO}_{2, \mathrm{pig}}=0.123 \mathrm{BW}^{0.62}$ & Literature review \\
\hline Pedersen et al. (2008) & $\mathrm{E}-\mathrm{CO}_{2, \mathrm{pig}}=0.0998 \mathrm{BW}^{0.646}$ & Literature review \\
\hline This review & $\mathrm{E}-\mathrm{CO}_{2, \text { pig }}=0.136 \mathrm{BW}^{0.573}$ & Literature review \\
\hline
\end{tabular}




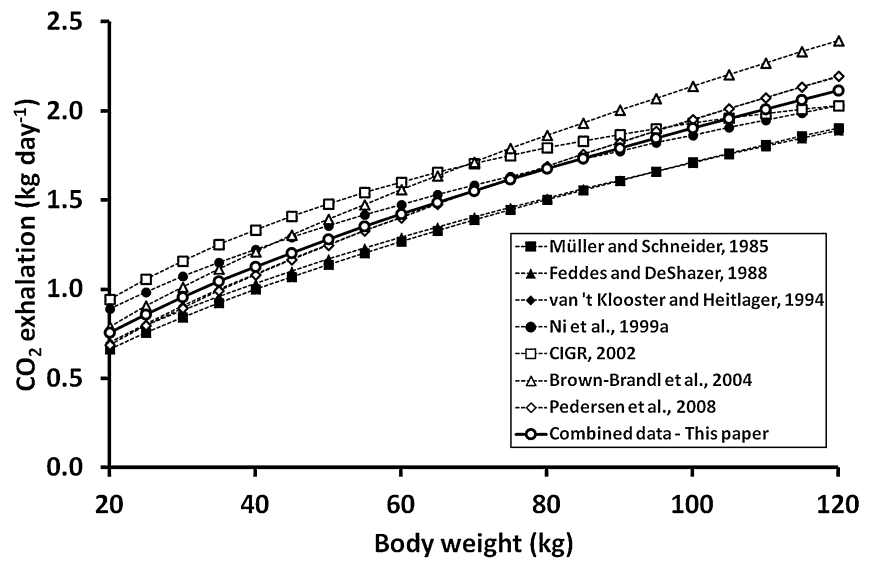

Fig. 1. Carbon dioxide $\left(\mathrm{CO}_{2}\right)$ exhalation by pigs estimated according to body weight.

Greater enteric production by sows can be explained by several factors, including increased feeding capacity, better intrinsic ability of bacterial flora to digest fibre, a greater number of bacteria, a reduction in the relative feeding level, and increased transit time (Le Goff et al., 2002a). Fig. 2 illustrates the production of enteric $\mathrm{CH}_{4}$ for fattening pigs and adult sows reported in the literature according to the level of fibre intake, the so-called digestible residues (dRes), as proposed in INRA-AFZ (2004) and defined as the difference between digested organic matter and digested protein, fat, starch and sugar. By compiling these data, the following equations have been developed to predict the $\mathrm{CH}_{4}$ enteric production $\left(\mathrm{E}-\mathrm{CH}_{4}\right.$,pig/sow, in $\mathrm{g} \mathrm{CH}_{4} \mathrm{day}^{-1}$ ) from dRes intakes $\left(\right.$ g day $^{-1}$ ) for fattening pigs (Eq. (2)) and for adult sows (Eq. (3)):

$\mathrm{E}-\mathrm{CH}_{4, \text { pig }}=0.012 \times \mathrm{dRes}\left(R^{2}=0.77\right)$

$\mathrm{E}-\mathrm{CH}_{4, \text { sow }}=0.021 \times \mathrm{dRes}\left(R^{2}=0.90\right)$

For example, the ingestion of $300 \mathrm{~g}$ of dRes is associated with the enteric production of $3.6 \mathrm{~g} \mathrm{CH}_{4}$ by fattening pigs and $6.3 \mathrm{~g} \mathrm{CH}_{4}$ by adult sows. Enteric emissions represent energy losses of $56.65 \mathrm{~kJ}$ per $\mathrm{g}$ of $\mathrm{CH}_{4}$ produced, which represents about $0.4-0.5 \%$ of digestible energy (DE) for fattening pigs and 1.0-1.5\% DE for adult sows. According to the tier 1 methodology from the IPCC guidelines for national inventories (IPCC, 2006), enteric $\mathrm{CH}_{4}$ is estimated at $1.5 \mathrm{~kg}$ per head per year, corresponding to $4.1 \mathrm{~g} \mathrm{CH}_{4}$ day $^{-1}$, whatever the diet composition and physiological stage. Taking

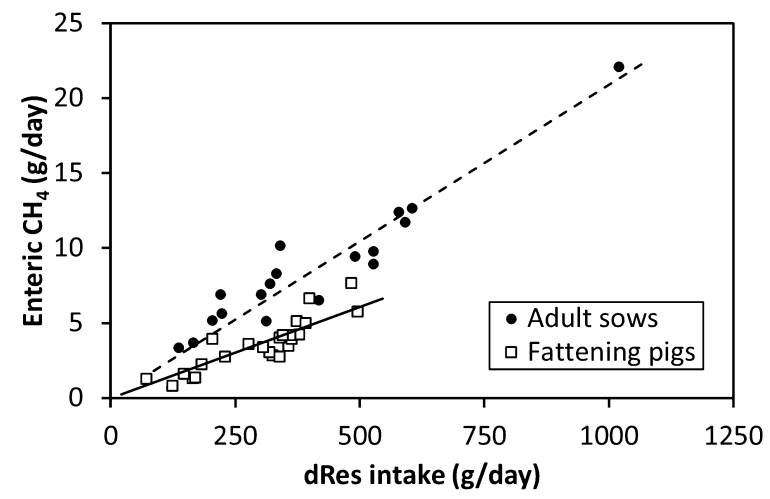

Fig. 2. Estimations of enteric methane $\left(\mathrm{CH}_{4}\right)$ production by adult sows and fattening pigs according to the intake of digestive residues (dRes defined as the difference between digested organic matter and digested protein, fat, starch and sugar).Source: adapted from Noblet et al., 1994; Jorgensen et al., 1996; Olesen and Jorgensen, 2001; Le Goff et al., 2002a,b; Ramonet et al., 2000; Galassi et al., 2004, 2005; Jorgensen, 2007; Jorgensen et al., 2007; Serena et al., 2008. into account conventional diet composition, level of ingestion and/ or growth performance Vermorel et al. (2008) estimated for French production daily enteric $\mathrm{CH}_{4}$ emissions to $0.8,2.4$ and $8.2 \mathrm{~g} \mathrm{CH}_{4}$ head $^{-1}$ for weaned piglets (up to $20 \mathrm{~kg}$ ), fattening pigs (from $20 \mathrm{~kg}$ ) and reproductive sows, respectively. Corresponding values for German production were proposed by Dämmgen et al. (2012a) at $0.9,2.5$ and $6.1 \mathrm{~g} \mathrm{CH}_{4}$, respectively.

\subsubsection{Release from manure}

The release of $\mathrm{CH}_{4}$ from manure originates from the temporal succession of microbial processes (Hellmann et al., 1997; Monteny et al., 2006). Initially, unspecified bacteria convert easily degradable substrates into VFAs, $\mathrm{CO}_{2}$ and $\mathrm{H}_{2}$. This extensive microbial activity increases the temperature of the manure and provides suitable conditions for methanogenic bacteria to convert acetate, $\mathrm{CO}_{2}$ and $\mathrm{H}_{2}$ into methane under a thermophilic environment. Factors that favour $\mathrm{CH}_{4}$ production are lack of oxygen, high temperature, a high level of degradable organic matter, high moisture content, a low redox potential, a neutral $\mathrm{pH}$, and a $\mathrm{C} / \mathrm{N}$ ratio of between 15 and 30 (Moller et al., 2004; Amon et al., 2006; Kebreab et al., 2006).

According to the guidelines for National Greenhouse Gas Inventories (IPCC, 2006), $\mathrm{CH}_{4}$ emissions from manure $\left(\mathrm{E}-\mathrm{CH}_{4}\right.$, manure, in $\mathrm{m}^{3}$ ) can be estimated based on the amount of excreted volatile solid (VS) or organic matter (OM), in kg; the ultimate $\mathrm{CH}_{4}$ potential $\left(B_{0}\right)$, in $\mathrm{m}^{3} \mathrm{CH}_{4}$ per $\mathrm{kg}$ VS or $\mathrm{OM}$; and the methane conversion factor $(\mathrm{MCF})$, in percentage:

$\mathrm{E}-\mathrm{CH}_{4}$, manure $=\mathrm{VS} \times \mathrm{B}_{0} \times \mathrm{MCF}$

The IPCC (2006) recommends values for VS, $B_{0}$ and MCF, depending on the region of the world, the climate, the livestock categories and the type of manure. In Western Europe, the recommended value for VS is $0.30 \mathrm{~kg} \mathrm{pig}^{-1} \mathrm{day}^{-1}$ (IPCC, 2006). In the literature, $B_{0}$ values vary from 0.29 to $0.53 \mathrm{~m}^{3}$ per $\mathrm{kg}$ VS or OM (Moller et al., 2004; Chae et al., 2008; Vedrenne et al., 2008; Jarret et al., 2011; Dämmgen et al., 2012b). The $B_{0}$ value proposed by the IPCC (2006) is $0.45 \mathrm{~m}^{3}$ per $\mathrm{kg}$ VS. In the literature, extreme MCF values range from $2 \%$ to $80 \%$ according to manure type, manure management, storage duration, diet composition and temperature (Moller et al., 2004; Jarret et al., 2011; Dämmgen et al., 2012b; Rodhe et al., 2012). In their study, Moller et al. (2004) showed that during long-term storage (90 days), the slurry MCF value increased from 5.3 to $31.3 \%$ at temperatures ranging from 15 to $20^{\circ} \mathrm{C}$, respectively. On the other hand, at high temperatures, reducing the storage duration from 90 to 30 days decreased the MCF to $10.9 \%$. Taking into account the proportion of manure management system usage, the emission factor for gas releases from swine manure in temperate Western Europe is estimated to $12 \mathrm{~kg} \mathrm{CH}_{4}$ head $^{-1}$ year $^{-1}$, or $32.9 \mathrm{~g} \mathrm{CH}_{4}$ day $^{-1}$, including inside and outside storage (IPCC, 2006).

\subsection{Nitrous oxide}

In pig houses, $\mathrm{N}_{2} \mathrm{O}$ originates only from manure. Its formation mainly occurs during incomplete nitrification/denitrification processes performed by micro-organisms that normally convert $\mathrm{NH}_{3}$ into non-polluting molecular nitrogen $\left(\mathrm{N}_{2}\right)$. The main microbial pathways involved in $\mathrm{N}_{2} \mathrm{O}$ synthesis are presented in Fig. 3. An abiotic conversion of ammonium under acidic conditions, so-called chemo-denitrification, can also be at the origin of $\mathrm{N}_{2} \mathrm{O}$ (Oenema et al., 2005; Petersen and Miller, 2006).

Nitrification, the process that converts ammonia into nitrate $\left(\mathrm{NO}_{3}{ }^{-}\right)$, is usually carried out by autotrophic bacteria that require aerobic conditions with a $\mathrm{pH}$ value of above 5 (Kebreab et al., 2006). During nitrification, $\mathrm{N}_{2} \mathrm{O}$ is synthesized as a by-product when there is a lack of oxygen and/or a nitrite accumulation. Denitrification is the reduction of $\mathrm{NO}_{3}{ }^{-}$into $\mathrm{N}_{2}$, with many 
(a) Nitrification

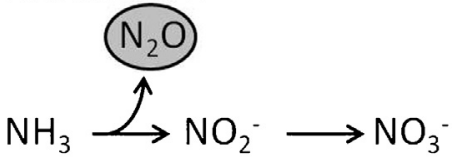

(b) Denitrification

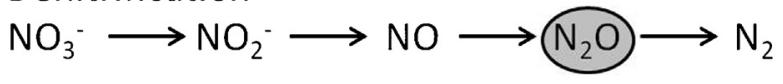

(c) Nitrifier denitrification

$$
\mathrm{NH}_{3} \longrightarrow \mathrm{NO}_{2}^{-} \longrightarrow \mathrm{NO} \longrightarrow \mathrm{N}_{2} \mathrm{O} \longrightarrow \mathrm{N}_{2}
$$

\section{(d) Anamox}

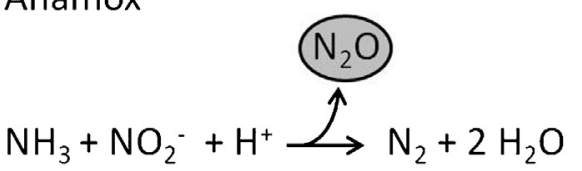

Fig. 3. Microbial pathways involved in $\mathrm{N}_{2} \mathrm{O}$ synthesis in manure.

intermediate compounds being produced during the process $\left(\mathrm{NO}_{2}{ }^{-}\right.$, nitric oxide $(\mathrm{NO})$, and $\left.\mathrm{N}_{2} \mathrm{O}\right)$. In manure, denitrification is principally performed by heterotrophic facultative aerobic bacteria. The accumulation of $\mathrm{N}_{2} \mathrm{O}$ in manure is favoured in the presence of oxygen and/or low availability of degradable carbohydrates (Poth and Focht, 1985; Driemer and Van den Weghe, 1997). The production of $\mathrm{N}_{2} \mathrm{O}$ can also occur during other microbial pathways: the oxidation of ammonium under aerobic or anaerobic conditions, the so-called nitrifier denitrification and anamox processes, respectively. Most nitrifying and denitrifying microorganisms are mesophilic, and thus, the formation of $\mathrm{N}_{2} \mathrm{O}$ is generally inhibited by temperatures above $40-50^{\circ} \mathrm{C}$ (Hellmann et al., 1997; Kebreab et al., 2006). However, some authors have detected $\mathrm{N}_{2} \mathrm{O}$ synthesis under thermophilic conditions (Wolter et al., 2004; Szanto et al., 2007). The relative contribution of these numerous pathways has still to be determined. Nevertheless, $\mathrm{N}_{2} \mathrm{O}$ synthesis is known to require a close combination of aerobic and anaerobic areas. These heterogeneous conditions are largely encountered within litter but are rarer in slurry. However, $\mathrm{N}_{2} \mathrm{O}$ emissions can occur from slurry when a dry crust is formed on the surface containing a combination of anaerobic and aerobic micro-sites. In any case, $\mathrm{N}_{2} \mathrm{O}$ production from manure has a highly stochastic nature, especially due to its numerous sources of emission and environmental controls.

The guidelines for National Greenhouse Gas Inventories (IPCC, 2006) recommend estimating direct $\mathrm{N}_{2} \mathrm{O}$ emissions by multiplying $\mathrm{N}$ excreted by animals $\left(\mathrm{N}_{\mathrm{ex}}\right)$ by a specific conversion factor for each type of manure management system. For example, this conversion factor is $0.2 \% \mathrm{~N}_{\mathrm{ex}}$ for pit storage under animals and $1 \% \mathrm{~N}_{\mathrm{ex}}$ for deep bedding. Assuming $40 \mathrm{~g} \mathrm{~N}_{\mathrm{ex}} \mathrm{pig}^{-1} \mathrm{day}^{-1}$, this represents 0.13 and

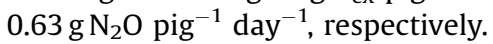

\section{Contribution by physiological stage}

Several authors have measured GHG emissions from pig houses under practical conditions. Table 4 summarizes results from

Table 4

Emission factors at house level for carbon dioxide $\left(\mathrm{CO}_{2}\right)$, methane $\left(\mathrm{CH}_{4}\right)$ and nitrous oxide $\left(\mathrm{N}_{2} \mathrm{O}\right)$ related to the physiological stage of the pigs $($ kept on a slatted floor).

\begin{tabular}{|c|c|c|c|c|c|}
\hline \multirow[t]{2}{*}{ Physiological stage } & \multirow[t]{2}{*}{ Country } & \multicolumn{4}{|c|}{ Greenhouse gas emissions ( $\mathrm{kg} \mathrm{CO}_{2}$ equiv. $\mathrm{LU}^{-1}$ day $^{-1}$ ) } \\
\hline & & $\mathrm{CO}_{2}$ & $\mathrm{CH}_{4}$ & $\mathrm{~N}_{2} \mathrm{O}$ & Total \\
\hline \multicolumn{6}{|l|}{ Gestating sows } \\
\hline Lägue et al., 2004 & Canada & 11.98 & 2.13 & 0.00 & 14.10 \\
\hline Dong et al., 2007 & China & 5.92 & 0.24 & 0.22 & 6.38 \\
\hline Zhang et al., 2007 & USA & 8.16 & 2.39 & 0.00 & 10.55 \\
\hline Costa and Guarino, 2009 & Italy & 8.85 & 3.30 & 0.81 & 12.96 \\
\hline Philippe et al., 2011a & Belgium & 5.70 & 0.60 & 0.33 & 6.63 \\
\hline Stinn et al., 2011 & USA & 8.95 & 7.07 & 0.03 & 16.04 \\
\hline Mean & & 8.26 & 2.62 & 0.23 & 11.11 \\
\hline \multicolumn{6}{|l|}{ Farrowing sows } \\
\hline Lägue et al., 2004 & Canada & 21.50 & 4.56 & 0.00 & 26.06 \\
\hline Dong et al., 2007 & China & 7.49 & 0.24 & 0.16 & 7.89 \\
\hline Zhang et al., 2007 & USA & 14.08 & 6.69 & 0.00 & 20.77 \\
\hline Stinn et al., 2011 & USA & 27.86 & 3.59 & 0.07 & 31.53 \\
\hline Mean & & 17.73 & 3.77 & 0.06 & 21.56 \\
\hline \multicolumn{6}{|l|}{ Weaned piglets } \\
\hline Lägue et al., 2004 & Canada & 29.85 & 14.69 & 0.00 & 44.54 \\
\hline Dong et al., 2007 & China & 29.67 & 1.46 & 0.38 & 31.51 \\
\hline Cabaraux et al., 2009 & Belgium & 10.70 & 0.74 & 0.05 & 11.48 \\
\hline Costa and Guarino, 2009 & Italy & 6.00 & 0.61 & 1.08 & 7.69 \\
\hline Mean & & 19.05 & 4.37 & 0.38 & 23.81 \\
\hline \multicolumn{6}{|l|}{ Fattening pigs } \\
\hline Nicks et al., 2005 & Belgium & 13.86 & 3.24 & 0.75 & 17.85 \\
\hline Dong et al., 2007 & China & 16.73 & 0.80 & 0.26 & 17.79 \\
\hline Philippe et al., 2007a & Belgium & 12.84 & 3.01 & 1.19 & 17.04 \\
\hline Costa and Guarino, 2009 & Italy & 13.64 & 4.75 & 0.97 & 19.35 \\
\hline Palkovicova et al., 2009 & Slovak Republic & 14.36 & 5.76 & 0.91 & 21.02 \\
\hline Guingand et al., 2010 & France & 17.82 & 1.95 & 0.47 & 20.24 \\
\hline Li et al., 2011 & USA & 16.20 & 0.53 & 1.71 & 18.44 \\
\hline Ngwabie et al., 2011 & Sweden & 16.38 & 3.78 & 0.37 & 20.53 \\
\hline Mean & & 15.23 & 2.98 & 0.83 & 19.03 \\
\hline
\end{tabular}

$\mathrm{CO}_{2}$ equiv.: emissions of $\mathrm{CO}_{2}$-equivalents, including $\mathrm{CO}_{2}, \mathrm{CH}_{4}$ and $\mathrm{N}_{2} \mathrm{O}$, taking into account the global warming potential of 25 and 298 for $\mathrm{CH}_{4}$ and $\mathrm{N}_{2} \mathrm{O}$, respectively.

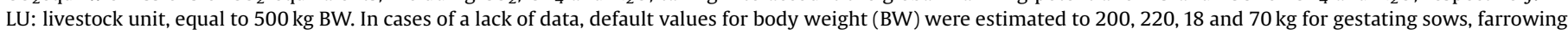
sows (including piglets), weaned piglets and fattening pigs, respectively. 
research involving the study of $\mathrm{CO}_{2}, \mathrm{CH}_{4}$ and $\mathrm{N}_{2} \mathrm{O}$ together for pigs kept on slatted floors at their different physiological stages. In order to facilitate a comparison between physiological stages and between gases, emissions are expressed in the table as $\mathrm{CO}_{2}$-equivalents per livestock unit. The $\mathrm{CO}_{2}$-equivalents ( $\mathrm{CO}_{2}$ equiv.) take into account the global warming potential of each gas, which is evaluated to 25 and 298 times that of $\mathrm{CO}_{2}$ over a 100 -year period for $\mathrm{CH}_{4}$ and $\mathrm{N}_{2} \mathrm{O}$, respectively (IPCC, 2007). The livestock unit (LU) is equal to $500 \mathrm{~kg}$ body weight.

The $\mathrm{CO}_{2}$ emissions related to fattening pigs are quite similar between the studies, while the corresponding values for the other physiological stages shows greater variation, especially for weaned piglets. Similar findings have also been observed by Philippe et al. (2011b) regarding $\mathrm{NH}_{3}$ emissions. The discrepancy between the results of the studies, as shown in Table 4, may be attributed to differences in housing conditions, ventilation systems, management practices, diet formulation and gas measurement method. Nevertheless, the average emission factors proposed by physiological stage seem consistent between the studies. Indeed, gestating sows present the lowest value $\left(8.26 \mathrm{~kg} \mathrm{CO}_{2} \mathrm{LU}^{-1}\right.$ day $^{-1}$, or $3.3 \mathrm{~kg} \mathrm{CO}_{2}$ sow $^{-1}$ day $^{-1}$ ), as influenced by their low feed intake (restricted feeding, low energy density of the diet) and metabolism. Farrowing sows (including piglets) and weaned piglets are associated with the highest emissions $\left(17.73 \mathrm{~kg} \mathrm{CO}_{2} \mathrm{LU}^{-1} \mathrm{day}^{-1}\right.$, or $8.87 \mathrm{~kg} \mathrm{CO}_{2}$ sow $^{-1} \mathrm{day}^{-1}$, and $19.05 \mathrm{~kg} \mathrm{CO}_{2} \mathrm{LU}^{-1} \mathrm{day}^{-1}$, or $0.69 \mathrm{~kg}$ $\mathrm{CO}_{2} \mathrm{pig}^{-1} \mathrm{day}^{-1}$, respectively), as a consequence of ad libitum feeding and intensive productive status (milk production and growth). Emissions related to fattening pigs $\left(15.3 \mathrm{~kg} \mathrm{CO}_{2} \mathrm{LU}^{-1}\right.$ day $^{-1}$, or $2.1 \mathrm{~kg} \mathrm{CO}_{2} \mathrm{pig}^{-1} \mathrm{day}^{-1}$ ) are slightly lower than the latter.

The $\mathrm{CH}_{4}$ emissions reported in the literature present a large range of variation within each physiological stage. In addition to the variation factors described above for $\mathrm{CO}_{2}$, the manure removal strategy and the storage duration inside the building seem to play an important role regarding the level of emissions (see below). For the other physiological stages, higher emissions were also observed with a longer duration of indoor manure storage. Table 4 shows that, on average, the mean emission factors expressed per LU do not differ significantly between physiological stages, ranging from $2.62 \mathrm{~kg}$ $\mathrm{CO}_{2}$ equiv. $\mathrm{LU}^{-1}$ day $^{-1}$ for gestating sows, to $4.37 \mathrm{~kg} \mathrm{CO}_{2}$ equiv. $\mathrm{LU}^{-1}$ day $^{-1}$ for weaned piglets, with intermediate values for fattening pigs (2.98 $\mathrm{kg} \mathrm{CO} \mathrm{CO}_{2}$ equiv. $\mathrm{LU}^{-1}$ day $^{-1}$ ) and farrowing sows $(3.77 \mathrm{~kg}$ $\mathrm{CO}_{2}$ equiv. $\mathrm{LU}^{-1}$ day $^{-1}$ ). Corresponding values expressed per animal are $41.9,6.3,16.7$ and $78.5 \mathrm{~g} \mathrm{CH}_{4}$ day $^{-1}$, respectively. The $\mathrm{CH}_{4}$ emissions associated with gestating sows could be deemed quite low, considering the high fibre content of their diet and their large fermentative capacity. In fact, these effects are counterbalanced by the restricted feeding usually applied at this stage.
As can be seen in Table 4, the $\mathrm{N}_{2} \mathrm{O}$ emissions measured from pig houses fitted with a slatted floor were relatively low whatever the pigs' physiological stage. In some experiments (Lägue et al., 2004; Zhang et al., 2007), the production of $\mathrm{N}_{2} \mathrm{O}$ emissions was even lower than the detection limit of the measurement equipment, giving small mean values as a result. In this context, important relative differences between studies or physiological stages do not have significant meaning. Thus, it seems more appropriate to consider a generic emission factor for all the stages. Based on the values reported in Table 4 , an average emission of $0.40 \mathrm{~kg} \mathrm{CO}_{2}$ equiv. $\mathrm{LU}^{-1}$ day $^{-1}$ could be proposed.

Also based on these values, total GHG emissions from pig buildings are estimated to $11.11 \mathrm{~kg} \mathrm{CO} \mathrm{CO}_{2}$ equiv. $\mathrm{LU}^{-1} \mathrm{day}^{-1}$ for gestating sows and around $20 \mathrm{~kg} \mathrm{CO}_{2}$ equiv. $\mathrm{LU}^{-1}$ day $^{-1}$ for lactating sows, weaned piglets and fattening pigs, reflecting the relative metabolism rate of each physiological stage.

The contribution of each physiological stage to GHG emission intensity expressed per unit of product is estimated using the data from Table 4 and is presented in Table 5. Overall, GHG emissions from pig houses are estimated to $448.4 \mathrm{~kg} \mathrm{CO}$ equiv. per slaughter pig produced or $4.87 \mathrm{~kg} \mathrm{CO}$ equiv. per $\mathrm{kg}$ carcass. The fattening period accounts for more than $70 \%$ of total emissions, while the gestation, lactation and weaning periods each contribute to about $10 \%$ of total emissions. Thus, it can be concluded that efforts to reduce emissions should primarily target fattening pigs. Emissions of $\mathrm{CO}_{2}, \mathrm{CH}_{4}$ and $\mathrm{N}_{2} \mathrm{O}$ contribute to 81,17 and $2 \%$ of total emissions from buildings, representing $3.87,0.83$ and $0.17 \mathrm{~kg} \mathrm{CO}_{2}$ equiv. per $\mathrm{kg}$ carcass, respectively. These figures show the important share of $\mathrm{CO}_{2}$ in global emissions contributed by pigs and their manure. However, these sources of emission are usually neglected in GHG evaluation. Indeed, several authors have developed life cycle assessment (LCA) studies to estimate the intensity of emissions given off in pig production. These models exclude $\mathrm{CO}_{2}$ emissions from respiration and manure but include GHG emissions for feed production, manure storage and spreading, and energy consumption. Reported values range from 3.07 to $5.79 \mathrm{~kg} \mathrm{CO}$ equiv. per $\mathrm{kg}$ carcass (Vergé et al., 2009; Pelletier et al., 2010; Lesschen et al., 2011; Weiss and Leip, 2012). The discrepancy between these studies comes from the differences in methodology, type of pig production, boundaries of the system, emission categories and allocation.

\section{Influencing factors}

The GHG emissions from pig houses are principally influenced by floor type, manure management and nutrition of the pigs. The climatic conditions inside the building also impact emission levels.

Table 5

Contribution of the physiological stage of pigs on greenhouse gas emissions per unit of product (assuming no allocation to slaughter by-products).

\begin{tabular}{|c|c|c|c|c|}
\hline \multirow[t]{2}{*}{ Physiological stage } & \multirow[t]{2}{*}{ Days } & \multicolumn{3}{|c|}{ Greenhouse gas emissions ( $\mathrm{kg} \mathrm{CO}_{2}$ equiv. $^{\mathrm{a}}$ ) } \\
\hline & & $\mathrm{Day}^{-1} \mathrm{animal}^{-1 \mathrm{~b}}$ & 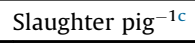 & $\mathrm{kg}_{\text {carcass }^{-1 d}}$ \\
\hline Dry and gestating sows & 125 & 4.44 & 55.6 & $0.60(12 \%)$ \\
\hline Lactating sows ${ }^{\mathrm{e}}$ & 28 & 10.78 & 30.2 & $0.33(7 \%)$ \\
\hline Weaned piglets ${ }^{\mathrm{f}}$ & 50 & 0.86 & 42.8 & $0.47(10 \%)$ \\
\hline Fattening pigs ${ }^{g}$ & 120 & 2.67 & 319.9 & $3.48(71 \%)$ \\
\hline Total & 323 & - & 448.4 & $4.87(100 \%)$ \\
\hline
\end{tabular}




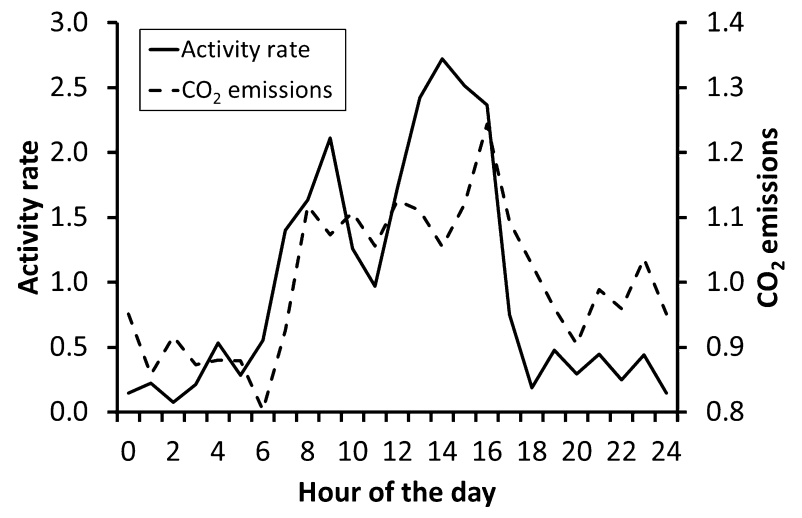

Fig. 4. Nycthemeral evolution around the daily mean (value $=1$ ) of the activity rate of pigs and the carbon dioxide emissions associated with fattening pigs kept on a slatted floor.Source: adapted from Philippe et al., 2013.

\subsection{Climatic conditions}

Gaseous emissions are positively related to temperature and ventilation rate. An experiment carried out in a commercial pig house emptied of pigs showed that $\mathrm{CO}_{2}$ emissions from slurry doubled when the manure temperature increased from 15 to $20^{\circ} \mathrm{C}$, and increased from 0.8 to $25.8 \mathrm{~g} \mathrm{CO}_{2} \mathrm{~h}^{-1}$ per $\mathrm{m}^{2}$ of slurry when the ventilation rate ranged from 160 to $3350 \mathrm{~m}^{3} \mathrm{~h}^{-1}$ (Ni et al., 1999b). Ngwabie et al. (2011) reported that $\mathrm{CH}_{4}$ emissions doubled when the indoor temperature in a fattening pig unit increased from 16.8 to $22.8^{\circ} \mathrm{C}$. Blanes-Vidal et al. (2008) estimated the correlation between averaged ventilation flow and $\mathrm{CH}_{4}$ emission to be 0.79 on an hourly basis.

Typically, gaseous emissions from pig houses present a diurnal pattern as a consequence of the comprehensive effects of temperature, ventilation rate and animal activity. The highest emission rates are usually observed during feeding time (Van Milgen et al., 1997; Moehn et al., 2004). For fattening pigs fed ad libitum, a first peak of emission occurs in the morning and a second peak in the afternoon, as illustrated for $\mathrm{CO}_{2}$ emissions in Fig. 4 (adapted from Philippe et al., 2013). Modification of the feeding schedule can have an impact on the level of daily emissions, as demonstrated by Groenestein et al. (2003) with gestating sows.

The location of the fans in the building also contributes to a modulation of the emission levels. Air inlets or outlets located near the manure surface increase the level of emissions due to greater air flow at the interface (Hayes et al., 2006). In any case, using climate conditions to modulate the release of GHGs seems rather impractical since the ambient parameters must primarily respect the physiological needs of the animals. Nevertheless, optimization of the heating and ventilation in the housing system can have a beneficial effect on emission levels. Good practice includes insulation of the building, adaptation to internal (e.g. density of the pigs and their physiological stage) and external factors (e.g. season and weather), management of air circulation and regular monitoring of the ventilation devices. Regulation of climatic parameters also has an influence on the health, performance, welfare and behaviour of the pigs, thereby causing indirect effects on the level of emissions. In addition, energy saving related to optimal management of climatic factors can be considered environmentally and economically beneficial.

\subsection{Floor type and manure management}

In pig production, the most frequent housing conditions are based on a slatted floor with a deep pit underneath for the storage of slurry. Alongside this traditional system, bedded systems have met with renewed interest during recent decades, as these systems are related to improved welfare, reduced odour nuisance and a better brand image for livestock production. For both housing systems, a large range of parameters may influence the levels of GHG emissions.

\subsubsection{Slatted floor systems}

4.2.1.1. Proportion of the slatted area. It is usually assumed that the emission of pollutant gases can be reduced by lowering the slurry emitting surface. With the implementation of a partly slatted floor, some authors have observed a reduction in $\mathrm{CO}_{2}$ production by $7-13 \%$ compared with a fully slatted floor, confirming that slurry is not the main source of emission (Table 6; Sun et al., 2008; Guingand et al., 2010). For $\mathrm{CH}_{4}$ production, contradictory results have been reported in the literature, with decreased emissions (Lägue et al., 2004; Philippe et al., 2014a) or increased emissions being associated with partly slatted floors (Guingand et al., 2010). The effect of a slatted floor area on $\mathrm{N}_{2} \mathrm{O}$ emissions has also shown conflicting results (Fitamant et al., 1999; Lägue et al., 2004; Guingand et al., 2010; Philippe et al., 2014a). In any case, absolute $\mathrm{N}_{2} \mathrm{O}$ emissions from slurry have been shown to remain quite low, whatever the type of slatted floor. Cumulative emissions of GHGs (expressed in $\mathrm{CO}_{2}$-equiv.) have been shown to be reduced by $4-13 \%$ by the application of a partly slatted floor compared with a fully slatted floor (Table 6).

Costs associated with partly slatted floors are quite similar to those of fully slatted floors despite a slightly higher labour cost due to pen fouling and the need for additional cleaning (Krieter, 2002). Application of partly slatted floors in existing fully slatted buildings is rather limited. Solid plates can be easily placed on the floor to create a partly slatted floor, but the total surface of the pit will remain unchanged, with no potential effects on emissions.

4.2.1.2. Slurry removal strategy. The increase in the slurry level could favour emissions, since it has been suggested that a smaller space between the slats and the surface of manure increases air turbulence and the release of gases (Ye et al., 2009). However, several authors have reported that a higher slurry depth does not

Table 6

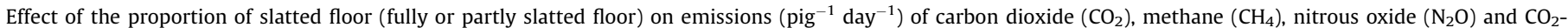

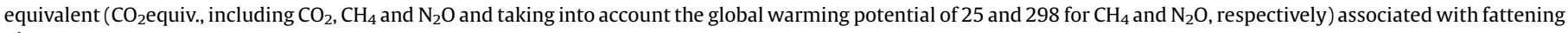
pigs.

\begin{tabular}{|c|c|c|c|c|c|c|c|c|}
\hline \multirow[t]{2}{*}{ References } & \multicolumn{4}{|c|}{ Fully slatted floor } & \multicolumn{4}{|c|}{ Partly slatted floor } \\
\hline & $\mathrm{CO}_{2}(\mathrm{~kg})$ & $\mathrm{CH}_{4}(\mathrm{~g})$ & $\mathrm{N}_{2} \mathrm{O}(\mathrm{g})$ & $\mathrm{CO}_{2}$ equiv. (kg) & $\mathrm{CO}_{2}(\mathrm{~kg})$ & $\mathrm{CH}_{4}(\mathrm{~g})$ & $\mathrm{N}_{2} \mathrm{O}(\mathrm{g})$ & $\mathrm{CO}_{2}$ equiv. (kg) \\
\hline Fitamant et al., 1999 & - & - & 1.10 & - & - & - & 1.59 & - \\
\hline Lägue et al., 2004 & 6.00 & 28.0 & 0.07 & 6.72 & 5.88 & 15.6 & 0.00 & 6.27 \\
\hline Sun et al., 2008 & 3.38 & - & - & - & 2.95 & - & - & - \\
\hline Guingand et al., 2010 & 2.48 & 9.7 & 0.19 & 2.78 & 2.31 & 11.2 & 0.24 & 2.66 \\
\hline Philippe et al., 2014a & 1.45 & 5.4 & 0.23 & 1.64 & 1.46 & 4.8 & 0.21 & 1.65 \\
\hline
\end{tabular}


promote the release of gases (Lägue et al., 2004; Haeussermann et al., 2006).

Nevertheless, frequent removal of manure has been proposed as a means to diminish the release of emissions from pig buildings. Total emissions within outside storage will also be reduced provided the temperature is lower outside than inside or where specific manure treatments are applied. In their study of $\mathrm{CH}_{4}$ and $\mathrm{N}_{2} \mathrm{O}$ emissions from pig units, Osada et al. (1998) showed that weekly removal of manure reduced the level of these emissions by about $10 \%$ compared with the traditional deep-pit system. With the same removal strategy, Guarino et al. (2003) observed a reduction of $19 \%$ in $\mathrm{CH}_{4}$ emissions, but a doubling of $\mathrm{N}_{2} \mathrm{O}$ emissions. Yet cumulative emissions (expressed in $\mathrm{CO}_{2}$-equiv.) were shown to be lowered by $16 \%$. Lavoie et al. (2006) found that when manure was removed three times a week instead of only once, $\mathrm{CH}_{4}$ emissions were reduced by $16 \%$ and $\mathrm{N}_{2} \mathrm{O}$ emissions remained insignificant. Results from these three studies regarding $\mathrm{CO}_{2}$ emissions would suggest that the level of these emissions is not impacted by the removal frequency of manure (Osada et al., 1998; Guarino et al., 2003; Lavoie et al., 2006).

Pit flushing is also an efficient means to mitigate emissions. Sommer et al. (2004) estimated to $35 \%$ the reduction potential of cumulative GHGs $\left(\mathrm{CH}_{4}\right.$ and $\left.\mathrm{N}_{2} \mathrm{O}\right)$ with daily flushing compared with having a static pit. By combining frequent flushing (six times a day) with a reduced slurry surface, Lagadec et al. (2012) measured a $35 \%$ reduction in cumulative emissions $\left(\mathrm{CH}_{4}\right.$ and $\left.\mathrm{N}_{2} \mathrm{O}\right)$ with the use of manure gutters and by $55 \%$ with the use of a flushing tube, compared with having a static pit. Kroodsma et al. (1993) showed that the frequency, duration and pressure of the flushing water also impacted the efficiency of mitigation. Their results demonstrated that frequent flushing (every $1-2 \mathrm{~h}$ ) for short periods (2s) was more effective than prolonged (3-6s) but less frequent flushing (every $3.5 \mathrm{~h}$ ). The use of fresh water, as opposed to recycled water, has also been found to further reduce emissions (Kroodsma et al., 1993). This is especially the case for $\mathrm{CH}_{4}$ because methanogenesis is rapidly initiated in the channel if a small proportion of the slurry remains in the pit after emptying. Without inoculums in the pit, $\mathrm{CH}_{4}$ formation is low and is initiated after a few days (Sommer et al., 2007).

Accumulated manure can also be removed by scraping. The standard flat scraper system consists of a shallow slurry pit with a horizontal steel scraper under the slatted floor, allowing the manure to be removed from the building every day or several times a week (Groenestein, 1994). With this system, reductions of $15 \%$ for $\mathrm{CO}_{2}$ emissions and of around $50 \%$ for $\mathrm{CH}_{4}$ and $\mathrm{N}_{2} \mathrm{O}$ emissions have been obtained under experimental conditions (Godbout et al., 2006; Lagadec et al., 2012). However under practical conditions, this technique has failed to significantly reduce $\mathrm{CH}_{4}$ emissions (Lagadec et al., 2012).

Other systems have been developed to associate manure removal with under-slat separation of liquid/solid fractions. The V-shaped scraper system involves a channel with two inclined surfaces on each side of a central gutter. The liquid fraction runs off continuously under the force of gravity towards the gutter, and the solid fraction remaining on the inclined surfaces is frequently scraped (Godbout et al., 2006). These authors observed that, when manure was scraped every 2-3 days, although $\mathrm{CO}_{2}$ emissions remained unchanged, $\mathrm{CH}_{4}$ emissions reduced by $20 \%$, in comparison with a deep-pit emptied once a week. Furthermore, Lagadec et al. (2012) demonstrated a 50\% reduction in $\mathrm{N}_{2} \mathrm{O}$ emissions in the case of a scraping frequency of between 3 and 12 times a day, compared with having a static pit. With the V-shaped conveyor belt system, urine constantly flows down in the middle of the belt under the force of gravity, and faeces are removed by the rotation of the belt (de Vries et al., 2013). Results obtained by de Vries et al. (2013) showed that this technique reduced $\mathrm{CO}_{2}$ emissions by $47 \%$ and $\mathrm{CH}_{4}$ emissions by $90 \%$, but increased $\mathrm{N}_{2} \mathrm{O}$ emissions by $250 \%$. Overall, cumulative emissions $\left(\mathrm{CO}_{2}, \mathrm{CH}_{4}\right.$ and $\left.\mathrm{N}_{2} \mathrm{O}\right)$ were lowered by 80\% (de Vries et al., 2013).

Implementation of elementary frequent manure removal techniques does not seem to be associated with extra cost and could be easily applied in existing buildings. By contrast, flushing strategies (using manure gutters or flushing tubes) require major modifications to be made to existing houses. For new buildings, these systems are economically advantageous due to the reduced requirement to dig a shallow pit and the low operational costs (Guarino et al., 2003). For scraping systems, buildings costs are estimated to be higher than for traditional deep pit systems, i.e. +25 to $+35 \%$ per animal place (Hamel et al., 2004; Lagadec et al., 2012). Aarnink et al. (2007) estimate the cost for new buildings to be fitted with $\mathrm{V}$-shaped conveyor belts to be $10-15 \%$ lower than for traditional systems. However, applicability of these latest techniques in existing houses would appear difficult owing to the required modification of the existing manure outlets.

4.2.1.3. Other techniques. Some other original techniques have been developed to reduce GHG emissions from pig houses. Incorporation of humic acids into slurry has been shown to reduce $\mathrm{CH}_{4}$ emissions by $34 \%$ by improving methanotrophic bacteria, but not to modify $\mathrm{CO}_{2}$ or $\mathrm{N}_{2} \mathrm{O}$ emissions (Shah and Kolar, 2012). The addition of quebracho tannins into slurry has also been shown to reduce $\mathrm{CH}_{4}$ emissions by up to $95 \%$ due to the noxious effects of these compounds on methanogens. Soybean oil sprinkling and misting with essential oils have been shown to decrease $\mathrm{CO}_{2}$ and $\mathrm{CH}_{4}$ emissions by about 20\% (Ni et al., 2008). By contrast, the addition of clay or zeolite to slurry has been shown to result in increased $\mathrm{CH}_{4}$ emissions, as a consequence of the neutralization of the toxic effect of ammonia on methanogenic bacteria (Hansen et al., 1999; Kotsopoulos et al., 2008). The use of $\mathrm{TiO}_{2}$-based paints and coatings has been shown to reduce $\mathrm{CH}_{4}$ emissions by up to $27 \%$ due to the oxidative photocatalytic properties of the chemical (Costa et al., 2012). These findings would need to be confirmed in further studies and, in some cases, the underlying mechanisms require clarification.

4.2.1.4. Outside storage and slurry treatment. The release of gases during the outside storage of slurries is influenced by numerous factors. Seasonal and weather conditions, such as air temperature, relative humidity, wind speed and rainfall, modulate the production of GHGs from slurry (Lägue et al., 2004). Natural or synthetic coverings have been proposed as a means of mitigating emissions by reducing the emitting area, heating and turbulence at the slurry surface. However, some authors have reported increased emissions despite slurry cover (Loyon et al., 2006; Guarino et al., 2006; Van der Zaag et al., 2008). Several slurry treatments have been developed to facilitate the management of emissions and to mitigate their environmental impact. These slurry treatments include, among others, solid-liquid separation, biofiltration, vermifiltration and aerobic or anaerobic treatments (Godbout et al., 2003; Lägue et al., 2004; Loyon et al., 2007; Dinuccio et al., 2008; Lessard et al., 2009; Luth et al., 2011). Generally, strategies that reduce GHG emissions from slurry, preserve its energetic and agronomic values, and favour nutrient uptake for next steps are environmentally efficient. Among the numerous techniques available, anaerobic digestion of slurry with the production of a biogas rich in $\mathrm{CO}_{2}$ and $\mathrm{CH}_{4}$ offers an interesting opportunity to significantly reduce GHG emissions due to a lowered release of gases from manure, the production of renewable energy (electricity and heat) and the replacement of fossil fuel consumption. Adoption of an anaerobic digester in a pig farm for 100 fattening places has been estimated to offset a total of $125 \mathrm{t}$ $\mathrm{CO}_{2}$ equiv. per year (Kaparaju and Rintala, 2011). The different 
techniques used to treat manure can be combined, and numerous modifications/adaptations have been developed. The level of GHG emissions related to these techniques depends on various parameters such as the type and the duration of treatment, the stage of the process, and the volume and the composition of the manure fraction. Thus, knowledge of the specific conditions for the treatment is essential for precise environmental assessment.

\subsubsection{Bedded floor systems}

Compared with slatted floor systems, bedded floor systems are usually associated with reduced $\mathrm{CH}_{4}$ emissions, increased $\mathrm{CO}_{2}$ emissions, hugely elevated $\mathrm{N}_{2} \mathrm{O}$ emissions, and an overall increase in $\mathrm{CO}_{2}$ equiv. emissions (Table 7 ). The specific environment encountered within the litter, especially the combination of aerobic and anaerobic areas, as opposed to strictly anaerobic slurry, explains these emission factors. Nevertheless, bedded systems combine a wide range of rearing techniques that impact the level of emissions. Indeed, the litter may differ by the bedding material, the amount and frequency of application, the space allowance, the litter management and the removal strategy. These parameters influence the physico-chemical characteristics of the manure, such as density, humidity, temperature, $\mathrm{pH}$ and $\mathrm{C} / \mathrm{N}$ ratio, all of which interact to modulate gas emission levels (Dewes, 1996; Groenestein and Van Faassen, 1996; Misselbrook and Powell, 2005).

Implementation of a bedded system is associated with low building costs due to reduced digging requirements. This technique may also be easily applicable in existing buildings with a concrete solid floor. However, the price of bedding material and the labour involved in litter management induce an increased cost, estimated to be between +5 and $10 \%$ compared with slatted floor systems (Krieter, 2002; Philippe et al., 2006b). The availability of substrates may constitute important opportunities or limitations of application, resulting in a different economic balance from area to area.

4.2.2.1. Type of substrate. Several bedding materials have been tested regarding their GHG emissions. The most frequent substrate used is straw, but sawdust, wood shavings or peat may also be used (Jeppsson, 1998; Robin et al., 1999; Nicks, 2004). Results of studies comparing straw litters and sawdust litters show that sawdust litters produce fewer $\mathrm{CH}_{4}$ emissions but hugely greater $\mathrm{N}_{2} \mathrm{O}$ emissions (Table 8 ). Table 8 shows that, overall, the $\mathrm{CO}_{2}$ equiv. emissions from these studies are higher with the use of sawdust; this is mainly due to the greater contribution of $\mathrm{N}_{2} \mathrm{O}$ emissions. Interactions within the litter may explain these results. Indeed, the higher manure density observed with sawdust impairs the composting process, which normally increases the temperature of the manure and amount of air exchange through it (Jeppsson, 2000). Comparing different bedding types under barn conditions, Jeppsson (2000) found manure temperatures of 23.9 and $35.5^{\circ} \mathrm{C}$, respectively, with wood shavings and chopped straw. Lower temperatures favour the activity of nitrifying and denitrifying bacteria, with a higher level of $\mathrm{N}_{2} \mathrm{O}$ production as a by-product (Sommer, 2001; Hansen et al., 2006). By contrast, $\mathrm{CH}_{4}$ production is very heat-dependent, and lower temperatures will significantly diminish these emissions (Hansen et al., 2006). Husted (1994) found that emissions of $\mathrm{CH}_{4}$ from dung heaps could be divided by a factor ranging from 2.7 to 10.3 when heap temperatures were decreased by $10^{\circ} \mathrm{C}$. Moreover, $\mathrm{CH}_{4}$ production is also controlled by the rate of its transport throughout the manure and by oxidation (Conrad, 1989). If $\mathrm{CH}_{4}$ production is reduced and the path of its spread is slow in the presence of oxygen, oxidation is likely to occur and consequently lower $\mathrm{CH}_{4}$ emissions will be released (Hao and Larney, 2011). Thus, the oxidation of $\mathrm{CH}_{4}$ into $\mathrm{CO}_{2}$ could counterbalance the reduction in $\mathrm{CO}_{2}$ production via the composting process.

4.2.2.2. Amount of substrate and frequency of application. Studies of the effect of the amount of substrate on GHG emissions have shown conflicting results, except for $\mathrm{N}_{2} \mathrm{O}$, for which reductions have been systematically observed with increased amounts of bedding material (Yamulki, 2006; Sommer and Moller, 2000; Guingand and Rugani, 2013; Philippe et al., 2014b). Indeed, Guingand and Rugani (2013) reported that $\mathrm{N}_{2} \mathrm{O}$ emissions were lowered by $57 \%$ when straw supplies increased from 60 to $90 \mathrm{~kg}$ per fattening period. Higher aeration of the litter and/or increased temperatures may explain this finding. For $\mathrm{CO}_{2}$ and $\mathrm{CH}_{4}$ production, the underlying mechanisms seem unclear, since contradictions appear in the literature between authors (Jeppsson, 2000; Sommer and Moller, 2000; Yamulki, 2006; Rigolot et al., 2010; Guingand and Rugani, 2013; Philippe et al., 2014b). For instance, Jeppsson (2000) showed that an increase of $25 \%$ in straw supply was associated with increased $(+72 \%) \mathrm{CO}_{2}$ emissions, while Philippe et al. (2014b) observed unchanged emissions with a straw rate ranging from $50 \mathrm{~kg}$ to $100 \mathrm{~kg}$ per fattening pig. In practice, interactions between the microbial pathways and the physico-chemical properties of the litter modulate the level of emissions with variable effects according to specific conditions. The main characteristics of manure involved in these processes are dry matter content, $\mathrm{C} / \mathrm{N}$ ratio, availability of carbohydrates, aeration and temperature. Regarding $\mathrm{CH}_{4}$, on the one hand, extra substrate may inhibit gas production because of greater aeration (Rigolot et al., 2010; Yamulki, 2006; Sommer and

Table 7

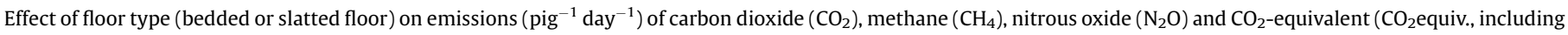
$\mathrm{CO}_{2}, \mathrm{CH}_{4}$ and $\mathrm{N}_{2} \mathrm{O}$ and taking into account the global warming potential of 25 and 298 for $\mathrm{CH}_{4}$ and $\mathrm{N}_{2} \mathrm{O}$, respectively).

\begin{tabular}{|c|c|c|c|c|c|c|c|c|c|}
\hline & \multicolumn{5}{|c|}{ Bedded floor } & \multicolumn{4}{|c|}{ Slatted floor } \\
\hline & Litter type & $\mathrm{CO}_{2}(\mathrm{~kg})$ & $\mathrm{CH}_{4}(\mathrm{~g})$ & $\mathrm{N}_{2} \mathrm{O}(\mathrm{g})$ & $\mathrm{CO}_{2}$ equiv. (kg) & $\mathrm{CO}_{2}(\mathrm{~kg})$ & $\mathrm{CH}_{4}(\mathrm{~g})$ & $\mathrm{N}_{2} \mathrm{O}(\mathrm{g})$ & $\mathrm{CO}_{2}$ equiv. (kg) \\
\hline \multicolumn{10}{|l|}{ Weaned piglets } \\
\hline Cabaraux et al., 2009 & Straw & 0.33 & 0.75 & 0.03 & 0.36 & 0.30 & 0.91 & 0.00 & 0.32 \\
\hline Cabaraux et al., 2009 & Sawdust & 0.43 & 0.52 & 0.32 & 0.54 & 0.34 & 0.86 & 0.01 & 0.36 \\
\hline \multicolumn{10}{|l|}{ Fattening pigs } \\
\hline Robin et al., 1999 & Sawdust & - & - & 4.72 & - & - & - & 0.79 & - \\
\hline Ahlgrimm and Breford, 1998 & Straw & - & 2.74 & - & - & - & 6.16 & - & - \\
\hline Kermarrec and Robin, 2002 & Sawdust & - & - & 5.53 & - & - & - & - & - \\
\hline Philippe et al., 2007a & Straw & 1.97 & 16.03 & 1.11 & 2.70 & 1.74 & 16.32 & 0.54 & 2.31 \\
\hline Philippe et al., 2007b & Straw & 1.77 & 8.88 & 0.68 & 2.19 & 1.61 & 15.20 & 0.67 & 2.19 \\
\hline \multicolumn{10}{|l|}{ Gestating sows } \\
\hline Philippe et al., 2011a & Straw & 2.83 & 9.20 & 2.27 & 3.74 & 2.41 & 10.12 & 0.47 & 2.80 \\
\hline
\end{tabular}


Table 8

Effect of the type of substrate on emissions ( pig $^{-1}$ day $\left.^{-1}\right)$ of carbon dioxide $\left(\mathrm{CO}_{2}\right)$, methane $\left(\mathrm{CH}_{4}\right)$, nitrous oxide $\left(\mathrm{N}_{2} \mathrm{O}\right)$ and $\mathrm{CO}_{2}$-equivalent $\left(\mathrm{CO}_{2}\right.$ equiv., including $\mathrm{CO}_{2}, \mathrm{CH}_{4}$ and $\mathrm{N}_{2} \mathrm{O}$ and taking into account the global warming potential of 25 and 298 for $\mathrm{CH}_{4}$ and $\mathrm{N}_{2} \mathrm{O}$, respectively) associated with a bedded system.

\begin{tabular}{|c|c|c|c|c|c|c|c|c|}
\hline & \multicolumn{4}{|c|}{ Straw-based deep litter } & \multicolumn{4}{|c|}{ Sawdust-based deep litter } \\
\hline & $\mathrm{CO}_{2}(\mathrm{~kg})$ & $\mathrm{CH}_{4}(\mathrm{~g})$ & $\mathrm{N}_{2} \mathrm{O}(\mathrm{g})$ & $\mathrm{CO}_{2}$ equiv. (kg) & $\mathrm{CO}_{2}(\mathrm{~kg})$ & $\mathrm{CH}_{4}(\mathrm{~g})$ & $\mathrm{N}_{2} \mathrm{O}(\mathrm{g})$ & $\mathrm{CO}_{2}$ equiv. (kg) \\
\hline \multicolumn{9}{|l|}{ Weaned piglets } \\
\hline Nicks et al., 2003 & 0.46 & 1.58 & 0.36 & 0.61 & 0.48 & 0.77 & 1.39 & 0.91 \\
\hline Cabaraux et al., 2009 & 0.33 & 0.75 & 0.03 & 0.36 & 0.43 & 0.52 & 0.32 & 0.54 \\
\hline \multicolumn{9}{|l|}{ Fattening pigs } \\
\hline Nicks et al., 2004 & 1.30 & 7.39 & 0.03 & 1.49 & 1.32 & 4.96 & 2.09 & 2.07 \\
\hline
\end{tabular}

Moller, 2000). On the other hand, extra substrate may promote emissions by providing degradable carbohydrates for methanogenic bacteria (Guingand and Rugani, 2013; Philippe et al., 2014b).

The effect of the frequency of straw application has been addressed by Guingand and Rugani (2013). The authors observed increased emissions of $\mathrm{CH}_{4}(+40 \%)$ and $\mathrm{N}_{2} \mathrm{O}(+167 \%)$ when straw was supplied every week compared with every 2 weeks, although the total amount of straw was similar for both frequencies.

4.2.2.3. Surface area of the bedded area. Some studies have examined the impact on emissions of the surface area of the bedded area. Based on experimental data, Hassouna et al. (2005) proposed two emission factors for $\mathrm{N}_{2} \mathrm{O}$ emissions related to animal density: $4-12 \% \mathrm{~N}_{\mathrm{ex}}$ with less than $2 \mathrm{~m}^{2}$ fattening pig ${ }^{-1}$ and $2-8 \%$ $\mathrm{N}_{\mathrm{ex}}$ with more than $2 \mathrm{~m}^{2}$ fattening pig $^{-1}$. With gestating sows, Philippe et al. (2010) measured a reduction in $\mathrm{CO}_{2^{-}}, \mathrm{CH}_{4}$ - and $\mathrm{N}_{2} \mathrm{O}$ emissions by 12,33 and $28 \%$, respectively, when the available bedded area was increased from 2.5 to $3.0 \mathrm{~m}^{2}$ per animal.

4.2.2.4. Litter removal strategy. As in the case of slurry systems, manure removal strategies have been proposed to reduce pollutant emissions from bedded systems.

The height of a manure pile influences the level of GHG emissions. Under laboratory conditions, Dong et al. (2011) increased manure height from 10 to $40 \mathrm{~cm}$ by increasing the amount of manure from 6.6 to $22.8 \mathrm{~kg}$. The authors obtained a lowering of $\mathrm{CO}_{2}$ - and $\mathrm{N}_{2} \mathrm{O}$-emissions by 53 and $11 \%$, respectively, but a doubling of $\mathrm{CH}_{4}$ emissions, resulting from an increase in anaerobic conditions. With straw-based deep litters, GHG emissions increase regularly over the course of time throughout the same fattening period, principally due to the accumulation of dejection (Philippe et al., 2007a; Philippe et al., 2010; Philippe et al., 2012a). In their study, Nicks et al. (2004) found that the rearing of three successive batches of pigs on the same litter did not increase the $\mathrm{CO}_{2}$ and $\mathrm{N}_{2} \mathrm{O}$ emissions from one fattening period to another, but that it did significantly increase $\mathrm{CH}_{4}$ emissions from 3.3 to $12.7 \mathrm{~g} \mathrm{CH}_{4} \mathrm{pig}^{-1}$ day $^{-1}$ between the first and the third batch. Thus, frequent manure removal has been suggested as a means to mitigate emissions, and straw flow systems have been developed in response (Bruce, 1990). In this system, straw is supplied at the top of a sloped lying area. It travels down the slope with the aid of pig motion, is mixed with dung and then goes out of the pen into a passage from which manure is regularly scraped and removed. This kind of manure management is efficient in diminishing GHG emissions, as observed by Philippe et al. (2012a, who measured a reduction by 10,46 and $55 \%$ for $\mathrm{CO}_{2^{-}}, \mathrm{CH}_{4^{-}}$and $\mathrm{N}_{2} \mathrm{O}$-emissions, respectively, compared with deep-litter. Overall, these authors found that $\mathrm{CO}_{2}$ equiv. emissions (including $\mathrm{CO}_{2}, \mathrm{CH}_{4}$ and $\mathrm{N}_{2} \mathrm{O}$ ) were reduced by $50 \%$.

During the outside storage of solid manure, air temperature seems not to significantly influence the level of emissions, in contrast with wind speed or rainfall episodes (Wolter et al., 2004). Manure operations such as turning, stacking or covering impact on GHG emissions, but there have been some contradictory findings between studies (Hellmann et al., 1997; Paillat et al., 2005; Szanto et al., 2007; Jiang et al., 2013). Interlinked relationships between biological, physical and chemical factors inside the manure heap may explain these discrepancies. Whatever the storage conditions and treatment of manure, it is imperative that these conserve the energetic and agronomic value of the manure.

\subsection{Nutrition}

The main dietary strategy proposed for the abatement of pollutant gas emissions is the manipulation of the levels of crude protein and fibre content in the diet. Some dietary additives have also been studied for their impact on GHG emissions.

Evaluation of the cost-effectiveness of dietary manipulation is made difficult principally due to the large fluctuation in raw material prices depending on market conditions. For instance, the economic impact of the level of crude protein in the diet is greatly affected by the cost of soybean meal, on the one hand, and synthetic amino acids on the other hand. For the 2004-2008 period, Pineiro et al. (2009) found that the cost difference between reduced crude protein diet supplemented with amino acids and the standard diet fluctuated from +5 to $6 €$ per pig produced. Feedstuffs rich in dietary fibre are quite inexpensive since they are usually by-products of the feed, food or biofuel industries (e.g.: sugar beet pulp, wheat bran and distiller's grain). However, the price of high fibre diets greatly depends on local opportunities and the availability of such ingredients. Dietary manipulations are mitigation methods that are easy for farmers to apply and that can be adapted according to the circumstances.

\subsubsection{Crude protein content}

Diets reduced in crude protein content (CPC) but supplemented with amino acids have been given to pigs to match the protein supply with their growth potential and so to improve the efficiency of protein utilization, with similar zootechnical performance but with resulting reduced $\mathrm{N}$ excretion and $\mathrm{NH}_{3}$ production (Philippe et al., 2011b). Thus, it has been suggested that a lower CPC could also reduce $\mathrm{N}_{2} \mathrm{O}$ emissions, since $\mathrm{NH}_{3}$ is the precursor of the formation of $\mathrm{N}_{2} \mathrm{O}$ (Misselbrook et al., 1998). However, experiments have failed to corroborate this hypothesis (Table 9). Indeed, laboratory-scale experiments based on slurry samples have resulted in similar levels of $\mathrm{N}_{2} \mathrm{O}$ emissions despite CPC being reduced by 15-20\% (Clark et al., 2005; Le et al., 2009; Osada et al., 2011). Under barn conditions with fattening pigs on litter, Philippe et al. (2006a) reported a doubling of $\mathrm{N}_{2} \mathrm{O}$ emissions (1.02 vs.

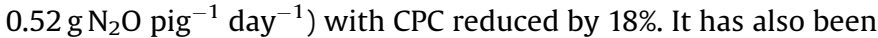
assumed that a lower $\mathrm{CPC}$ would reduce $\mathrm{CO}_{2}$ - and $\mathrm{CH}_{4}$-emissions due to improved nutrient utilization, but contradictory findings have also been observed for these gases (Table 9). In studies 
Table 9

Effects of a reduction in dietary crude protein content (CPC) on emissions of carbon dioxide $\left(\mathrm{CO}_{2}\right)$, methane $\left(\mathrm{CH}_{4}\right)$, nitrous oxide $\left(\mathrm{N}_{2} \mathrm{O}\right)$ and $\mathrm{CO}_{2}$-equivalents $\left(\mathrm{CO}_{2}\right.$ equiv., including $\mathrm{CO}_{2}, \mathrm{CH}_{4}$ and $\mathrm{N}_{2} \mathrm{O}$ and taking into account the global warming potential of 25 and 298 for $\mathrm{CH}_{4}$ and $\mathrm{N}_{2} \mathrm{O}$, respectively).

\begin{tabular}{|c|c|c|c|c|c|}
\hline References & $\mathrm{CO}_{2}$ & $\mathrm{CH}_{4}$ & $\mathrm{~N}_{2} \mathrm{O}$ & $\mathrm{CO}_{2}$ equiv. & Context \\
\hline Quiniou et al., 1995 & $+7 \%$ & - & - & - & Respiratory chambers, fattening pigs, 17.7 vs. $24.3 \%$ CPC \\
\hline Atakora et al., 2002 & $-5 \%$ & - & - & - & Respiratory chambers, gestating sows, 14.8 vs. $19.3 \%$ CPC \\
\hline Atakora et al., 2002 & $-7 \%$ & - & - & - & Respiratory chambers, lactating sows, 12.0 vs. $16.3 \%$ CPC \\
\hline Atakora et al., 2003 & NS & $-60 \%$ & - & - & Respiratory chambers, non-pregnant sows, $11 . \%$ vs. $14.6 \%$ CPC \\
\hline Atakora et al., 2005 & NS & NS & - & - & Respiratory chambers, fattening pigs, 11.2 vs. $16.8 \%$ CPC \\
\hline Atakora et al., 2011a & NS & $-27 \%$ & - & - & Respiratory chambers, fattening pigs, 12.0 vs. $19.5 \%$ СРC \\
\hline Atakora et al., 2011b & NS & $-19 \%$ & - & - & Respiratory chambers, fattening pigs, 16.2 vs. $19.0 \%$ CPC \\
\hline Clark et al., 2005 & $+10 \%$ & $+10 \%$ & NS & $+10 \%$ & Slurry samples, fattening pigs, 13.9 vs. $16.8 \%$ CPC \\
\hline Velthof et al., 2005 & - & $-21 \%$ & - & - & Slurry samples, fattening pigs, 14.2 vs. $18.0 \%$ CPC \\
\hline Le et al., 2009 & NS & NS & NS & NS & Slurry samples, fattening pigs, 12.0 vs. $15.0 \%$ CPC \\
\hline Osada et al., 2011 & - & NS & NS & - & Slurry samples, fattening pigs, 14.5 vs. $17.0 \%$ CPC \\
\hline Philippe et al., 2006a & NS & $-13 \%$ & $+96 \%$ & $+7 \%$ & Pens with fattening pigs on straw litter, 14.4 vs. $17.6 \%$ СРC \\
\hline
\end{tabular}

involving respiratory chambers, most results have shown a nonsignificant difference in $\mathrm{CO}_{2}$-exhalation despite a $\mathrm{CPC}$ reduction of up to 45\% (Atakora et al., 2003, 2005, 2011a,b). Quiniou et al. (1995) measured an increase of $7 \%$ in respiratory $\mathrm{CO}_{2}$ production with fattening pigs, while Atakora et al. (2002) noted a decreased production of $5-7 \%$ with reproductive sows. Regarding $\mathrm{CH}_{4}$ emissions, some authors have reported reductions ranging from 13\% under field conditions (Philippe et al., 2006a) to 60\% in respiratory chambers (Atakora et al., 2002). Reduced VFA production with a low CPC diet could explain these results, since VFAs are precursors of $\mathrm{CH}_{4}$ (Velthof et al., 2005). However, nonsignificant differences or increases in $\mathrm{CH}_{4}$ production have also been obtained by some authors in cases of reduced CPC (Atakora et al., 2005; Clark et al., 2005; Le et al., 2009; Osada et al., 2011). Philippe et al. (2006a) reported a 7\% increase in cumulative GHG emissions (including $\mathrm{CO}_{2}, \mathrm{CH}_{4}$ and $\mathrm{N}_{2} \mathrm{O}$ ) with pigs on litter consuming a reduced CPC diet. This was due to a higher contribution of $\mathrm{N}_{2} \mathrm{O}$ despite lower $\mathrm{CH}_{4}$ emissions.

\subsubsection{Dietary fibre}

Several studies have dealt with the impact of dietary fibre on GHG emissions (Table 10). It has been established that diets rich in fibre increase $\mathrm{CH}_{4}$ production from both sources-animal and manure. Linear relationships were given in Section 2.2.1 for predicting enteric $\mathrm{CH}_{4}$ production from ingested dietary fibre. But digestive production can also be modulated by parameters such as the botanical origin, the solubility and the fermentability of the fibre (Philippe et al., 2008). An experiment on sows fed different diets with a similar dietary fibre content but different sources of fibre showed a higher $\mathrm{CH}_{4}$ production in cases where maize bran was incorporated compared with wheat bran (7.6 vs. $5.1 \mathrm{~g} \mathrm{CH}_{4}$ sow $^{-1}$ day $^{-1}$; Le Goff et al., 2002b). Indeed, soluble fibres, as found in maize bran, sugar beet pulp or potato pulp, have a higher digestibility and fermentability than insoluble fibres, as found in wheat bran, pea hulls or seed residues (Jorgensen et al., 2007).

Higher $\mathrm{CH}_{4}$ releases from slurry in cases of a fibrous diet have been reported under laboratory conditions by some authors (Clark et al., 2005; Velthof et al., 2005; Jarret et al., 2012). Jarret et al. (2012) compared $\mathrm{CH}_{4}$ production from the slurries of fattening pigs fed a conventional diet (11\% NDF) or a fibrous diet with $20 \%$ dried distiller's grain with solubles (DDGS; 14\% NDF) and they obtained higher emissions (+76\%) with the fibrous diet. The authors explained this result in terms of the lower digestibility of high fibre diets and thus the higher quantity of excreted OM ( 0.32 vs. $\left.0.19 \mathrm{~kg} \mathrm{pig}^{-1} \mathrm{day}^{-1}\right)$. The $B_{0}$ of excreta, on the other hand, did not differ significantly between treatments (around $0.38 \mathrm{~m}^{3}$ per $\mathrm{kg}$ OM). By contrast to these results, Clark et al. (2005) did not observe a significant difference in $\mathrm{CH}_{4}$ emissions under in vitro conditions, whatever the fibre content. At house level, $\mathrm{CH}_{4}$ emissions have been shown to increase by $13-52 \%$ with fibrous diets as much with a slatted floor as with a bedded floor (Philippe et al., 2009, 2012a,b, 2013; Pepple et al., 2011).

Regarding $\mathrm{CO}_{2}$ production, conflicting results have been reported depending on the study and the source of emissions (Table 10). Schrama et al. (1998) measured a 25\% lowering of $\mathrm{CO}_{2}$ exhalation as a consequence of a reduction in pig activity. At house level, Philippe et al. (2009) observed an increase of $24 \%$ in emissions with a diet based on sugar beet pulp (48\% NSP) compared with a conventional diet based on cereals (26\% NSP). The reduced feed efficiency observed with a fibrous diet could explain this result.

$\mathrm{N}_{2} \mathrm{O}$ emissions from slurry-based systems are unaffected by dietary fibre content (Clark et al., 2005; Pepple et al., 2011; Philippe et al., 2012b), in contrast to bedded systems, for which emissions have been shown to reduce with a high-fibre diet (Philippe et al., 2009, 2012b). In fact, with a fibrous diet, the pig's motivation to

Table 10

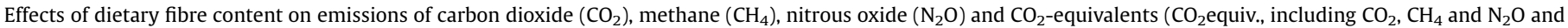
taking into account the global warming potential of 25 and 298 for $\mathrm{CH}_{4}$ and $\mathrm{N}_{2} \mathrm{O}$, respectively).

\begin{tabular}{|c|c|c|c|c|c|}
\hline References & $\mathrm{CO}_{2}$ & $\mathrm{CH}_{4}$ & $\mathrm{~N}_{2} \mathrm{O}$ & $\mathrm{CO}_{2}$ equiv. & Context \\
\hline Schrama et al., 1998 & $-25 \%$ & $+96 \%$ & - & - & Respiratory chambers, fattening pigs, 12 vs. $18 \%$ NSP (0 vs. $17 \%$ SBP) \\
\hline Wang et al., 2004 & $+6 \%$ & $+153 \%$ & - & - & Respiratory chambers, fattening pigs, 4 vs. $11.6 \%$ NSP (0 vs. $12 \%$ SBP) \\
\hline Li et al. 2011 & $-7 \%$ & $+93 \%$ & - & - & Environmentally controlled pens, fattening pigs, 32 vs. $40 \%$ NDF ( 0 vs. $20 \%$ DDGS) \\
\hline Clark et al., 2005 & $-17 \%$ & NS & NS & $-5 \%$ & Slurry samples from fattening pigs, 0 vs. $20 \%$ SBP \\
\hline Velthof et al., 2005 & - & $+74 \%$ & - & & Slurry samples from fattening pigs, 13 vs. $25 \%$ NSP \\
\hline Jarret et al., 2012 & - & $+76 \%$ & - & & Slurry samples from fattening pigs, 11 vs. $14 \%$ NDF (0 vs. $13 \%$ DDGS) \\
\hline Philippe et al., 2009 & $+24 \%$ & $+13 \%$ & $-61 \%$ & $+5 \%$ & Pens with gestating sows on straw litter, 26 vs. $48 \%$ NSP (7 vs. $42 \%$ SBP) \\
\hline Pepple et al., 2011 & $-13 \%$ & $+45 \%$ & NS & $+28 \%$ & Buildings with fattening pigs on a slatted floor, 0 vs. $20 \%$ DDGS \\
\hline Philippe et al., 2013 & $-9 \%$ & $+33 \%$ & NS & $-6 \%$ & Pen with fattening pigs on a slatted floor, 18 vs. $30 \%$ NSP (0 vs. $23 \%$ SBP) \\
\hline Philippe et al., 2012b & NS & $+44 \%$ & NS & $+6 \%$ & Pen with gestating sows on a slatted floor, 25 vs. $44 \%$ NSP ( 0 vs. $37 \%$ SBP) \\
\hline Philippe et al., 2012b & $+14 \%$ & $+52 \%$ & $-40 \%$ & $+9 \%$ & Pen with gestating sows on straw litter, 25 vs. $44 \%$ NSP (0 vs. $37 \%$ SBP) \\
\hline
\end{tabular}

NSP: non-starch polysaccharides; SBP: sugar beet pulp; NDF: neutral detergent fibre, DDGS: dried distiller's grain with solubles. 
manipulate and to chew the straw is reduced, as a sign of greater satiety (Philippe et al., 2008). Thus, the litter is more aerated with longer wisps of straw, which limits $\mathrm{N}_{2} \mathrm{O}$ production.

Overall, cumulative GHG emissions (combining $\mathrm{CO}_{2}, \mathrm{CH}_{4}$ and $\mathrm{N}_{2} \mathrm{O}$ ) seem to be little influenced by the presence of dietary fibre. This can be seen in reports by authors regarding emissions within a context of pigs receiving increased dietary fibre. Emission levels at house level ranged from -6 to $+9 \%$ compared with emissions produced by pigs consuming a conventional diet (Philippe et al., 2009, 2012a,b). An exception to this finding can be seen in the study of Pepple et al. (2011), who observed that $\mathrm{CO}_{2}$ equiv. emissions increased by $28 \%$ where pigs received a high fibre diet. The authors explained this result in terms of the large contribution of $\mathrm{CH}_{4}$ in their experimental conditions due to a long storage duration of slurries inside the building.

\subsubsection{Feed additives}

Several feed additives have been studied for their influence on environmental factors, especially on ammonia emissions, but few experiments have dealt with greenhouse gas emissions resulting from these additives.

Most studies have argued that feed supplementations that improve nutrient digestibility and growth performance in pigs potentially reduce pollutant gas emissions on an absolute scale and per product unit (Moehn et al., 2007). However, this statement has rarely been experimentally tested and validated.

Cellulases and hemicellulases have been added to animal diets in order to counterbalance the anti-nutritional effects of fermentable fibres and to improve animal performance (O'Shea et al., 2010). A further beneficial effect of these enzymes may be a reduction in $\mathrm{CH}_{4}$ production by enteric bacteria, which are linearly related to fibre ingestion. However, Moehn et al. (2007) observed a tendency for increased $\mathrm{CH}_{4}$ emissions despite xylanase supplementation.

Dietary inclusion of acidifying salts has also been suggested as a means to modify GHG production. Yet Aarnink et al. (2008) did not observe a significant difference in $\mathrm{CH}_{4}$ and $\mathrm{N}_{2} \mathrm{O}$ emissions despite the addition of $1 \%$ benzoic acid in the diet of fattening pigs. Eriksen et al. (2010) showed that a diet supplemented with $2 \%$ benzoic acid resulted in a transient reduction in $\mathrm{CH}_{4}$-emissions from slurries stored under laboratory conditions (from day 20 to 34 of storage). The authors explained this result in terms of the inhibition of methanogenic bacteria, possibly due to a reduction in manure $\mathrm{pH}$, the toxic effect of sulphides or the direct impact of benzoic acid. The temporality of the reduction could reflect the adaptation of the bacteria to slurry acidification.

Yucca extract inclusion has been proposed as a means to inhibit urease activity and to chemically convert or bind $\mathrm{NH}_{3}$ (Duffy and Brooks, 1998), leading to an improvement in the performance and health status of pigs (Colina et al., 2001). However, Amon et al. (1995) measured an increase in $\mathrm{CO}_{2}$ production with the dietary addition of Yucca shidigera extract. The effects on $\mathrm{CH}_{4}$ and $\mathrm{N}_{2} \mathrm{O}$ emissions of the inclusion of Yucca extract in the diet of pigs are still unknown.

The addition of phytase, primarily used to reduce phosphorus excretion, has been shown to increase feed efficiency and protein deposition, and this could possibly lead to a decrease in emissions (Ball and Möhn, 2003). However, to the best of our knowledge, the addition of phytase has not been studied for its effect on GHG emissions.

Probiotic agents are believed to improve the microbial environment in the gut, leading to better digestibility, performance and health status as a result (Fuller, 1989; Tsukahara et al., 2001). Under laboratory conditions, Tsukahara et al. (2001) measured emissions from the intestinal content of piglets fed a diet supplemented with a mixture of live lactic acid bacteria
(Lactobacillus acidophilus,Bifidobacterium bifidum and Enterococcus faecalis). The authors obtained reductions of approximately 50 and $35 \%$ for $\mathrm{CO}_{2}$ - and $\mathrm{CH}_{4}$-emissions, respectively, explained by the fact that lactic acid bacteria are stoichiometrically less favourable to gas production (Stanier et al., 1986). Barn experiments would need to be carried out to confirm these findings on a larger scale.

\section{Conclusion}

This review has reported and analysed the results of studies in the literature regarding GHG emissions produced by animals and manure in pig houses. Taking into account the results regarding $\mathrm{CO}_{2^{-}}, \mathrm{CH}_{4^{-}}$and $\mathrm{N}_{2} \mathrm{O}$-production, cumulative emissions of GHGs produced by pigs and manure at pig house level are estimated to approximately $4.87 \mathrm{~kg} \mathrm{CO}$ equiv. per $\mathrm{kg}$ of carcass. Although $\mathrm{CO}_{2}$ is the main contributor of these emissions (accounting for about $81 \%)$, this gas is usually not included in the calculation of overall GHG production because it is assumed that $\mathrm{CO}_{2}$ emitted by livestock is compensated during photosynthesis by plants used as feed. In addition in the past, $\mathrm{CO}_{2}$ emissions from manure were often erroneously considered negligible, while they can represent up to $40 \%$ of respiratory production.

The production levels of $\mathrm{CO}_{2}$, as for $\mathrm{CH}_{4}$ and $\mathrm{N}_{2} \mathrm{O}$, can be altered by several factors, such as housing conditions, manure management and diet composition. For instance, comparisons between slatted and bedded floor systems show higher $\mathrm{CO}_{2}$ equiv. emissions from bedded floor systems due to greater $\mathrm{CO}_{2}$ emissions but mainly due to high $\mathrm{N}_{2} \mathrm{O}$ emissions that are not counterbalanced by the eventual reduction in $\mathrm{CH}_{4}$ emissions. While litter systems are usually associated with a better brand image and are commonly required for environmental labelling, the data reported in this review show that the environmental benefits are not always so obvious for all aspects of the production process. Moreover, GHG emissions from bedded systems greatly depend on the type, the amount and the frequency of substrate supply. These parameters may interact, with variable impacts, on emission levels. Further studies need to be carried out in order to understand more precisely the underlying phenomena and interactions that modulate GHG production from litter.

Whatever the floor type, frequent manure removal is an efficient means used to diminish GHG emissions from pig buildings on the condition that emissions from outside storage operations are prevented. This is particularly true for $\mathrm{CH}_{4}$ production, which increases greatly over the course of time and in ambient temperatures. Frequent manure removal seems particularly advantageous since manure treatments can be associated with the removal. In this sense, separation of the solid and liquid fractions of the slurry provides interesting opportunities. Indeed, this separation reduces storage requirements and transportation costs, and offers more homogenous materials for land spreading, recycling or other specific treatments in order to enhance the agronomic, energetic and environmental profitability of the processes.

Regarding dietary strategies, inclusion of fibre impacts on GHG production by increasing $\mathrm{CH}_{4}$ emissions from the digestive tract and from the manure. For gestating sows fed with a high fibre diet and kept on a straw based deep litter, concurrent reductions in $\mathrm{N}_{2} \mathrm{O}$ emissions have been observed, resulting in a limited effect on $\mathrm{CO}_{2}$ equiv. emissions. A reduction in dietary $\mathrm{CPC}$, which is wellknown to reduce $\mathrm{N}$ excretion, has been shown to fail to limit the release of $\mathrm{N}_{2} \mathrm{O}$ from manure. Other feeding strategies have also been used to investigate the assumption that improved nutrient utilization can lower GHG emissions. However, this statement has not been systematically proven in experiments, since diets supplemented with feed additives such as acidifying salts, Yucca 
extracts or probiotics seem ineffective in significantly reducing the intensity of GHG emissions. Nevertheless, innovative nutritional options could be examined in the future, as they appear to be efficient in reducing emissions. Recycling of the co-products from the feed-, food- or biofuel-processing industry into animal feed requires further investigation, as this could provide economical and ecological advantages due to the allocation of the cost and the impacts. Overall, feeding strategies offer the advantage of being easy to implement and quick to adapt according to the availability and cost of raw materials, which fluctuate temporally.

Good management practices that respect the physiological requirements of the animals and that promote their zootechnical potential will have beneficial consequences on performance and indirectly on the intensity of GHG emissions. In light of this, factors such as the design of the building, the regulation of bioclimatic parameters, the sanitary status of the herd and genetic selection may modulate the level of GHG production.

The choice of rearing technique is also guided by other elements, such as animal welfare, the agronomical value of manure, investment and operating costs. Specific field conditions lead to decisions in favour of mitigation techniques. Options presented in this review may contribute to a reduction in the intensity of emissions generated by pig production. However, in order to be universally efficient, these strategies would need to be integrated on a larger scale taking into account supplementary emissions associated with pre-, on- and post-farm processing, such as feed production, energy consumption, manure spreading and the transportation of animal and products.

\section{References}

Aarnink, A.J.A., Huis in 't Veld, J., Hol, J.M.G., Vermeij, I., 2007. Kempfarm Housing System for Growing-finishing Pigs: Environmental Emissions and Investment Costs. In Animal Sciences Group, Report 67. Wageningen University and Research Centre, Lelystad, The Netherlands.

Aarnink, A.J.A., Hol, A., Nijeboer, G.M., 2008. Ammonia Emission Factor for Using Benzoic Acid (1\% Vevovitall $\left.{ }^{\mathbb{R}}\right)$ in the Diet of Growing-Finishing Pigs. In Animal Sciences Group, Report 133. Wageningen University and Research Centre, Wageningen, The Netherlands p. 21.

Ahlgrimm, H., Breford, J., 1998. Methanemissionen aus der schweinemast. Landbauforschung Volkenrode 1, 26-34.

Amon, B., Kryvoruchko, V., Amon, T., Zechmeister-Boltenstern, S., 2006. Methane: nitrous oxide and ammonia emissions during storage and after application of dairy cattle slurry and influence of slurry treatment. Agric. Ecosyst. Environ. 112, 153-162.

Amon, M., Dobeic, M., Misselbrook, T.H., Pain, B.F., Phillips, V.R., Sneath, R.W., 1995. A farm scale study on the use of de-odorase(R) for reducing odor and ammonia emissions from intensive fattening piggeries. Bioresour. Technol. 51, 163-169.

Anderson, G.A., Smith, R.J., Bundy, D.S., Hammond, E.G., 1987. Model to predict gaseous contaminants in swine confinement buildings. J. Agric. Eng. Res. 37, 235-253.

Andersson, M., 1996. Performance of bedding materials in affecting ammonia emissions from pig manure. J. Agric. Eng. Res. 65, 213-222.

Atakora, J.K., Moehn, S., Sands, J.S., Ball, R.O., 2011a. Effects of dietary crude protein and phytase-xylanase supplementation of wheat grain based diets on energy metabolism and enteric methane in growing finishing pigs. Anim. Feed Sci. Technol. 166, 422-429.

Atakora, J.K.A., McMillan, D.J., Moehn, S., Ball, R.O., 2002. Low protein diet for sows: effects on production of carbon dioxide and heat. Adv. Pork Prod. 13, Abstract \#14.

Atakora, J.K.A., Moehn, S., Ball, R.O., 2003. Low protein diets for sows reduce greenhouse gas production. Adv. Pork Prod. 14, Abstract \#16.

Atakora, J.K.A., Moehn, S., Ball, R.O., 2005. Performance and greenhouse gas emission in finisher pigs fed very low protein diet. Adv. Pork Prod. 16, Abstract \#14.

Atakora, J.K.A., Moehn, S., Ball, R.O., 2011b. Enteric methane produced by finisher pigs is affected by dietary crude protein content of barley grain based, but not by corn based, diets. Anim. Feed Sci. Technol. 166-167, 412-421.

Aubry, A., Quiniou, N., Cozler, Y.L., Querne, M., 2004. New standardized criteria for GTE performances. Techni-Porc. 27, 37-41.

Ball, R.O., Möhn, S., 2003. Feeding strategies to reduce greenhouse gas emissions from pigs. Adv. Pork Prod. 14, 301-311.

Blanes-Vidal, V., Hansen, M.N., Pedersen, S., Rom, H.B., 2008. Emissions of ammonia, methane and nitrous oxide from pig houses and slurry: effects of rooting material, animal activity and ventilation flow. Agric. Ecosyst. Environ. 124, 237244.
Brown-Brandl, T.M., Nienaber, J.A., Xin, H., Gates, R.S., 2004. A literature review of swine heat production. Trans. ASAE 47, 259.

Bruce, J.M., 1990. Straw-flow - a high welfare system for pigs. Farm Build. Prog. 102, $9-13$.

Cabaraux, J.F., Philippe, F.X., Laitat, M., Canart, B., Vandenheede, M., Nicks, B., 2009. Gaseous emissions from weaned pigs raised on different floor systems. Agric. Ecosyst. Environ. 130, 86-92.

Chae, K., Jang, A., Yim, S., Kim, I.S., 2008. The effects of digestion temperature and temperature shock on the biogas yields from the mesophilic anaerobic digestion of swine manure. Bioresour. Technol. 99, 1-6.

CIGR, 2002. Fourth Report of Working Group on Climatization of Animal Houses. Heat and Moisture Production at Animal and House Levels. Danish Institute of Agricultural Sciences, Horsens, Denmark, pp. 45.

Clark, O.G., Moehn, S., Edeogu, I., Price, J., Leonard, J., 2005. Manipulation of dietary protein and nonstarch polysaccharide to control swine manure emissions. J. Environ. Qual. 34, 1461-1466.

Colina, J.J., Lewis, A.J., Miller, P.S., Fischer, R.L., 2001. Dietary manipulation to reduce aerial ammonia concentrations in nursery pig facilities. J. Anim. Sci. 79, 30963103.

Conrad, R., 1989. Control of methane production in terrestrial ecosystems. In: Andreae, M., Schimel, D. (Eds.), Exchange of Trace Gases Between Terrestrial Ecosystems and the Atmosphere. John Wiley \& Sons Ltd., Chichester, England, pp. 39-58.

Costa, A., Chiarello, G.L., Selli, E., Guarino, M., 2012. Effects of $\mathrm{TiO}_{2}$ based photocatalytic paint on concentrations and emissions of pollutants and on animal performance in a swine weaning unit. J. Environ. Manage. 96, 86-90.

Costa, A., Guarino, M., 2009. Definition of yearly emission factor of dust and greenhouse gases through continuous measurements in swine husbandry. Atmos. Environ. 43, 1548-1556.

Dämmgen, U., Amon, B., Hutchings, N.J., Haenel, H.D., Rösemann, C., 2012a. Data sets to assess methane emissions from untreated cattle and pig slurry and solid manure storage systems in the German and Austrian emission inventories. Landbauforschung Volkenrode 62, 1-19.

Dämmgen, U., Schulz, J., Klausing, H.K., Hutchings, N.J., Haenel, H.D., Rösemann, C., 2012b. Enteric methane emissions from German pigs. Landbauforschung Volkenrode 62, 83-96.

de Sousa, P., Pedersen, S., 2004. Ammonia emission from fattening pig houses in relation to animal activity and carbon dioxide production. Agricultural Engineering International: CIGR Ejournal VI, Manuscript BC04 003.

de Vries, J.W., Aarnink, A.J.A., Groot Koerkamp, P.W.G., De Boer, I.J.M., 2013. Life cycle assessment of segregating fattening pig urine and feces compared to conventional liquid manure management. Environ. Sci. Technol. 47, 1589-1597.

Dewes, T., 1996. Effect of pH, temperature, amount of litter and storage density on ammonia emissions from stable manure. J. Agric. Sci. 127, 501-509.

Dinuccio, E., Berg, W., Balsari, P., 2008. Gaseous emissions from the storage of untreated slurries and the fractions obtained after mechanical separation. Atmos. Environ. 42, 2448-2459.

Dong, H., Zhu, Z., Shang, B., Kang, G., Zhu, H., Xin, H., 2007. Greenhouse gas emissions from swine barns of various production stages in suburban Beijing, China. Atmos. Environ. 41, 2391-2399.

Dong, H., Zhu, Z., Zhou, Z., Xin, H., Chen, Y., 2011. Greenhouse gas emissions from swine manure stored at different stack heights. Anim. Feed Sci. Technol. 166, 557-561.

Driemer, J., Van den Weghe, H., 1997. Nitrous oxide emissions during nitrification and denitrification of pig manure. In: Voermans, J.A.M., Monteny, G.J. (Eds.), Proceedings of the International Symposium on Ammonia and Odour Control from Animal Production Facilities, Dutch Society of Agricultural Engineering, Wageningen, The Netherlands, Vinkeloord, The Netherlands, pp. 389-396.

Duffy, C., Brooks, P., 1998. Using Yucca schidigera in pig diets: effects on nitrogen metabolism. In: Lyons, T.P., Jacques, K.A. (Eds.), Biotechnology in the Feed Industry. Alltach, Nicholasville, Kentucky, USA, pp. 61.

Eriksen, J., Adamsen, A.P.S., Norgaard, J.V., Poulsen, H.D., Jensen, B.B., Petersen, S.O., 2010. Emissions of sulfur-containing odorants, ammonia, and methane from pig slurry: effects of dietary methionine and benzoic acid. J. Environ. Qual. 39, 10971107.

FAO, 2011. World Livestock 2011- Livestock in Food Security. FAO, Rome, Italy.

FAO, 2013a. Greenhouse Gas Emissions From Pig and Chicken Supply Chains - A Global Life Cycle Assessment. FAO, Roma, Italy.

FAO, 2013b. Greenhouse Gas Emissions From Ruminant Supply Chains - A Global Life Cycle Assessment. FAO, Roma, Italy.

Feddes, J.J.R., DeShazer, J.A., 1988. Feed consumption as a parameter for establishing minimum ventilation rates. Trans. ASAE 31, 571-575.

Fitamant, D., Quillien, J.P., Callarec, J., Morvan, J., Lemasle, M., Laplanche, A., 1999. Nitrogen distribution and net flow in the form of gas and liquid from a piggery. Journées Rech. Porcine 31, 99-104.

Fuller, R., 1989. Probiotics in man and animals. J. Appl. Microbiol. 66, 365-378.

Galassi, G., Crovetto, G.M., Rapetti, L., Tamburini, A., 2004. Energy and nitrogen balance in heavy pigs fed different fibre sources. Livest. Prod. Sci. 85, 253-262.

Galassi, G., Crovetto, G.M., Rapetti, L., 2005. Trend of energy and nitrogen utilization of high fibre diets in pigs from 100 to $160 \mathrm{~kg}$ bodyweight. Ital. J. Anim. Sci. 4, 149-157.

Godbout, S., Lague, C., Lemay, S.P., Marquis, A., Fonstad, T.A., 2003. Greenhouse gas and odour emissions from swine operations under liquid manure management in Canada. In: Commission Internationale de Génie Rural (Ed.), Proceedings of the International Symposium on Gaseous and Odour Emissions from Animal 
Production Facilities, Danish Institute for Agricultural Sciences, Foulum, Denmark, pp. 426-443.

Godbout, S., Lemay, S.P., Marquis, A., Pouliot, F., Larouche, J.P., Hamel, D., Lachance, I., Belzile, M., Dufour, V., Turgeon, N., 2006. Évaluation Technico-économique D'un Système De Séparation Liquide/solide Des Déjections À La Source Dans Un Bâtiment Porcin Et Les Impacts Sur L'environnement. Institut de Recherche et de Développement en Agro-environnement, Quebec, Canada.

Groenestein, C.M., 1994. Ammonia emission from pig houses after frequent removal of slurry with scrapers. Proceedings of the XII World Congress on Agricultural Engineering. CIGR, Merelbeke, Belgium, pp. 543-550.

Groenestein, C.M., Hendriks, M., den Hartog, L.A., 2003. Effect of feeding schedule on ammonia emission from individual and group-housing systems for sows. Biosyst. Eng. 85, 79-85.

Groenestein, C.M., Van Faassen, H.G., 1996. Volatilization of ammonia, nitrous oxide and nitric oxide in deep-litter systems for fattening pigs. J. Agric. Eng. Res. 65 269-274.

Guarino, A., Fabbri, C., Brambilla, M., Valli, L., Navarotto, P., 2006. Evaluation of simplified covering systems to reduce gaseous emissions from livestock manure storage. T. ASABE 49, 737-747.

Guarino, M., Fabbri, C., Navarotto, P., Valli, L., Mascatelli, G., Rossetti, M., Mazzotta, V., 2003. Ammonia, methane and nitrous oxide emissions and particulate matter concentrations in two different buildings for fattening pig. In: Commission Internationale de Génie Rural (Ed.), Proceedings of the International Symposium on Gaseous and Odour Emissions from Animal Production Facilities, Danish Institute for Agricultural Sciences Foulum, Denmark, pp. 140 149.

Guingand, N., Quiniou, N., Courboulay, V., 2010. Comparison of ammonia and greenhouse gas emissions from fattening pigs kept either on partially slatted floor in cold conditions or on fully slatted floor in thermoneutral conditions. Journées Rech. Porcine 42, 277-284.

Guingand, N., Rugani, A., 2013. Incidence de la réduction de la quantité de paille et de la fréquence des apports sur les émissions d'ammoniac: de GES et d'odeurs chez les porcs en engraissement. Journées Rech. Porcine 45, 141-142.

Haeussermann, A., Hartung, E., Gallmann, E., Jungbluth, T., 2006. Influence of season ventilation strategy, and slurry removal on methane emissions from pig houses. Agric. Ecosyst. Environ. 112, 115-121.

Hamel, D., Pouliot, F., Leblanc, R., Godbout, S., Von Bermuth, R.D., Hill, J., 2004 Évaluation Technico-économique D'un Système De Séparation Liquide-solide Des Déjections À La Source Dans Un Bâtiment Porcin Et Les Impacts Sur L'environnement. Centre de développement du porc du Québec, Ste Foy Québec, Canada.

Hansen, K.H., Angelidaki, I., Ahring, B.K., 1999. Improving thermophilic anaerobic digestion of swine manure. Water Res. 33, 1805-1810.

Hansen, M.N., Henriksen, K., Sommer, S.G., 2006. Observations of production and emission of greenhouse gases and ammonia during storage of solids separated from pig slurry: effects of covering. Atmos. Environ. 40, 4172-4181.

Hao, X., Larney, F.J., 2011. Reducing greenhouse gas emissions from animal manure. Manure Manage. Update 37-45.

Hassouna, M., Robin, P., Texier, C., Ramonet, Y., 2005. $\mathrm{NH}_{3}, \mathrm{~N}_{2} \mathrm{O}, \mathrm{CH}_{4}$ emissions from pig-on-litter systems. Proceedings of the International Workshop on Green Pork Production, Paris, France pp. 121-122.

Hayes, E.T., Curran, T.P., Dodd, V.A., 2006. Odour and ammonia emissions from intensive pig units in Ireland. Bioresour. Technol. 97, 940-948.

Hellmann, B., Zelles, L., Palojarvi, A., Bai, Q.Y., 1997. Emission of climate-relevant trace gases and succession of microbial communities during open-window composting. Appl. Environ. Microbiol. 63, 1011-1018.

Husted, S., 1994. Seasonal variation in methane emission from stored slurry and solid manures. J. Environ. Qual. 23, 585-592.

INRA-AFZ, 2004. Tables De Composition Et De Valeur Nutritive Des Matières Premières Destinées Aux Animaux D'élevage. INRA Editions, Paris France.

IPCC, 2006. IPPC Guidelines for National Greenhouse Gas Inventories. Institute for Global Environmental Strategies, Hayama, Japan.

IPCC, 2007. Climate Change 2007: The Physical Science Basis. Contribution of Working Group I to the Fourth Assessment Report of the Intergovernmenta Panel on Climate Change. Cambridge University Press, Cambridge, United Kingdom and New York, NY, USA.

Jarret, G., Cerisuelo, A., Peu, P., Martinez, J., Dourmad, J.-Y., 2012. Impact of pig diets with different fibre contents on the composition of excreta and their gaseous emissions and anaerobic digestion. Agric. Ecosyst. Environ. 160, 51-58.

Jarret, G., Martinez, J., Dourmad, J.-Y., 2011. Pig feeding strategy coupled with effluent management - fresh or stored slurry: solid phase separation - on methane potential and methane conversion factors during storage. Atmos. Environ. 45, 6204-6209.

Jeppsson, K.H., 1998. Ammonia emission from different deep-litter materials for growing-finishing pigs. Swed. J. Agric. Res. 28, 197-206.

Jeppsson, K.H., 2000. Carbon dioxide emission and water evaporation from deep litter systems. J. Agric. Eng. Res. 77, 429-440.

Jeppsson, K.H., 2002. Diurnal variation in ammonia, carbon dioxide and water vapour emission from an uninsulated: deep litter building for growing/finishing pigs. Biosyst. Eng. 81, 213-223.

Jiang, T., Schuchardt, F., Li, G.X., Guo, R., Luo, Y.M., 2013. Gaseous emission during the composting of pig feces from Chinese Ganqinfen system. Chemosphere 90, $1545-1551$.

Jorgensen, H., Zhao, X.Q., Eggum, B.O., 1996. The influence of dietary fibre and environmental temperature on the development of the gastrointestinal tract digestibility, degree of fermentation in the hind-gut and energy metabolism in pigs. Br. J. Nutr. 75, 365-378.

Jorgensen, H., 2007. Methane emission by growing pigs and adult sows as influenced by fermentation. Livestock Sci. 109, 216-219.

Jorgensen, H., Serena, A., Hedemann, M.S., Knudsen, K.E.B., 2007. The fermentative capacity of growing pigs and adult sows fed diets with contrasting type and level of dietary fibre. Livestock Sci. 109, 111-114.

Kaparaju, P., Rintala, J., 2011. Mitigation of greenhouse gas emissions by adopting anaerobic digestion technology on dairy: sow and pig farms in Finland. Renewable Energy 36, 31-41.

Kebreab, E., Clark, K., Wagner-Riddle, C., France, J., 2006. Methane and nitrous oxide emissions from Canadian animal agriculture: a review. Can. J. Anim. Sci. 86, 135158.

Kermarrec, C., Robin, P., 2002. Nitrogenous gas emissions during the rearing of pigs on sawdust litter. Journées Rech. Porcine 34, 155-160.

Kotsopoulos, T.A., Karamanlis, X., Dotas, D., Martzopoulos, G.G., 2008. The impact of different natural zeolite concentrations on the methane production in thermophilic anaerobic digestion of pig waste. Biosyst. Eng. 99, 105-111.

Krieter, J., 2002. Evaluation of different pig production systems including economic, welfare and environmental aspects. Archiv fur Tierzucht 45, 223-236.

Kroodsma, W., Tveld, J., Scholtens, R., 1993. Ammonia emission and its reduction from cubicle houses by flushing. Livestock Prod. Sci. 35, 293-302.

Lagadec, S., Landrain, B., Landrain, P., Hassouna, M., Robin, P., 2012. Systèmes d'évacuations fréquentes des déjections Rapport d'étude, Chambres d'agriculture de Bretagne, p. 10.

Lägue, C., Marquis, A., Godbout, S., Legace, R., Fonstad, T.A., Lemay, S.P., Joncas, R. Jaulin, L., 2004. Greenhouse Gas Emissions from Swine Operations in Québec and Saskatchewan: Benchmark Assessments. University of Saskatchewan, Saskatchewan, Canada.

Lavoie, J., Beaudet, Y., Létourneau, C., Godbout, S., Lemay, S., Belzile, M., Lachance, I., Pouliot, F., 2006. Evaluation de la qualité de l'air dans les porcheries équipées d'un système de séparation liquide-solide des déjections, Report R-460; IRSST Montréal, QC, Canada.

Le Goff, G., Dubois, S., Van Milgen, J., Noblet, J., 2002a. Influence of dietary fibre leve on digestive and metabolic utilisation of energy in growing and finishing pigs. Anim. Res. 51, 245-260.

Le Goff, G., Le Groumellec, L., van Milgen, J., Dubois, S., Noblet, J., 2002b. Digestibility and metabolic utilisation of dietary energy in adult sows: influence of addition and origin of dietary fibre. Br. J. Nutr. 87, 325-335.

Le, P.D., Aarnink, A.J.A., Jongbloed, A.W., 2009. Odour and ammonia emission from pig manure as affected by dietary crude protein level. Livestock Sci. 121, 267-274.

Lessard, P., Bourgault, C., LeBihan, Y., Turgeon, N., Aubry, G., Buelna, G., 2009. Treatment of pig slurry by a process of biofiltration: study of formation of methane. Can. J. Civil Eng. 36, 1958-1962.

Lesschen, J.P., van den Berg, M., Westhoek, H.J., Witzke, H.P., Oenema, O., 2011. Greenhouse gas emission profiles of European livestock sectors. Anim. Feed Sci. Technol. 166-167, 16-28.

Li, W., Powers, W., Hill, G.M., 2011. Feeding distillers dried grains with solubles and organic trace mineral sources to swine and the resulting effect on gaseous emissions. J. Anim. Sci. 89, 3286-3299.

Loyon, L., Guiziou, F., Beline, E., Peu, P., 2007. Gaseous emissions $\left(\mathrm{NH}_{3} \mathrm{~N}_{2} \mathrm{O}, \mathrm{CH}_{4}\right.$ and $\mathrm{CO}_{2}$ ) from the aerobic treatment of piggery slurry - comparison with a conventional storage system. Biosyst. Eng. 97, 472-480.

Loyon, L., Guiziou, F., Picard, S., Saint-Cast, P., 2006. Impact of peat and polystyrene ball covers on the ammonia emissions from the storage and spreading of pig slurry: a farm-scale study. DIAS Report, Plant Production, 129-131.

Luth, R.P., Germain, P., Lecomte, M., Landrain, B., Li, Y., Cluzeau, D., 2011. Earthworm effects on gaseous emissions during vermifiltration of pig fresh slurry. Bioresour. Technol. 102, 3679-3686.

Misselbrook, T.H., Chadwick, D.R., Pain, B.F., Headon, D.M., 1998. Dietary manipulation as a means of decreasing $\mathrm{N}$ losses and methane emissions and improving herbage $\mathrm{N}$ uptake following application of pig slurry to grassland. J Agric. Sci. 130, 183-191.

Misselbrook, T.H., Powell, J.M., 2005. Influence of bedding material on ammonia emissions from cattle excreta. J. Dairy Sci. 88, 4304-4312.

Moehn, S., Atakora, J., Sands, J., Ball, R., 2007. Effect of phytase-xylanase supplementation to wheat-based diets on energy metabolism in growingfinishing pigs fed ad libitum. Livestock Sci. 109, 271-274.

Moehn, S., Bertolo, R., Pencharz, P., Ball, R., 2004. Pattern of carbon dioxide production and retention is similar in adult pigs when fed hourly, but not when fed a single meal. BMC Physiol. 4, 11.

Moller, H.B., Sommer, S.G., Ahring, B.K., 2004. Biological degradation and greenhouse gas emissions during pre-storage of liquid animal manure. J. Environ. Qual. 33, 27-36.

Monteny, G.J., Bannink, A., Chadwick, D., 2006. Greenhouse gas abatement strategies for animal husbandry. Agric. Ecosyst. Environ. 112, 163-170.

Müller, W.. Schneider, B., 1985. Heat: water vapour and $\mathrm{CO}_{2}$ production in dairy cattle and pig housing. Part 1. Provisional planning data for the use of heat exchangers and heat pumps in livestock housing. Tieräztliche Umschau 40, 274-280.

Ngwabie, N.M., Jeppsson, K.H., Nimmermark, S., Gustafsson, G., 2011. Effects of animal and climate parameters on gas emissions from a barn for fattening pigs. Appl. Eng. Agric. 27, 1027-1037.

Ni, J.Q., Hendriks, J., Coenegrachts, J., Vinckier, C., 1999a. Production of carbon dioxide in a fattening pig house under field conditions I. Exhalation by pigs. Atmos. Environ. 33, 3691-3696. 
Ni, J.Q., Vinckier, C., Coenegrachts, J., Hendriks, J., 1999b. Effect of manure on ammonia emission from a fattening pig house with partly slatted floor. Livestock Prod. Sci. 59, 25-31.

Ni, J.-Q., Heber, A.J., Lim, T.T., Tao, P.C., Schmidt, A.M., 2008. Methane and carbon dioxide emission from two pig finishing barns. J. Environ. Qual. 37, 2001-2011.

Nicks, B., 2004. Technical characteristics and environmental aspects of breeding fattening pigs and weaned piglets on accumulated litters. Ann. Méd. Vét. 148, $31-38$.

Nicks, B., Laitat, M., Farnir, F., Vandenheede, M., Desiron, A., Verhaeghe, C., Canart, B., 2004. Gaseous emissions from deep-litter pens with straw or sawdust for fattening pigs. Anim. Sci. 78, 99-107.

Nicks, B., Laitat, M., Vandenheede, M., Desiron, A., Verhaeghe, C., Canart, B., 2003. Emissions of ammonia, nitrous oxide, methane, carbon dioxide and water vapor in the raising of weaned pigs on straw-based and sawdust-based deep litters. Anim. Res. 52, 299-308.

Nicks, B., Philippe, F.X., Laitat, M., Farnir, F., Canart, B., Vandenheede, M., 2005. Gaseous emissions in the raising of fattening pigs on fully slatted-floor or on straw-based deep litter. In: Krynski, A., Wrzesien, R. (Eds.), Animal and Environment. ISAH, Warsaw, Poland, pp. 373-377.

Noblet, J., Fortune, H., Shi, X., Dubois, S., 1994. Prediction of net energy value of feeds for growing pigs. J. Anim. Sci. 72, 344-354.

Noblet, J., Dourmad, J.Y., Le Dividich, J., Dubois, S., 1989. Effect of ambient temperature and addition of straw or alfalfa in the diet on energy metabolism in pregnant sows. Livestock Prod. Sci. 21, 309-324.

O'Shea, C.J., Sweeney, T., Lynch, M.B., Gahan, D.A., Callan, J.J., O'Doherty, J.V., 2010. Effect of beta-glucans contained in barley- and oat-based diets and exogenous enzyme supplementation on gastrointestinal fermentation of finisher pigs and subsequent manureodor and ammonia emissions. J. Anim. Sci. 88, 1411-1420.

Oenema, O., Wrage, N., Velthof, G., Groenigen, J.W., Dolfing, J., Kuikman, P., 2005. Trends in global nitrous oxide emissions from animal production systems. Nutr. Cycling Agroecosyst. 72, 51-65.

Olesen, C.S., Jorgensen, H., 2001. Effect of dietary fibre on digestibility and energy metabolism in pregnant sows. Acta Agric. Scand. Sect. A: Anim. Sci. 51, 200-207.

Osada, T., Rom, H.B., Dahl, P., 1998. Continuous measurement of nitrous oxide and methane emission in pig units by infrared photoacoustic detection. Trans. ASAE 41, 1109-1114.

Osada, T., Takada, R., Shinzato, I., 2011. Potential reduction of greenhouse gas emission from swine manure by using a low-protein diet supplemented with synthetic amino acids. Anim. Feed Sci. Technol. 166, 562-574.

Paillat, J.-M., Robin, P., Hassouna, M., Leterme, P., 2005. Predicting ammonia and carbon dioxide emissions from carbon and nitrogen biodegradability during animal waste composting. Atmos. Environ. 39, 6833-6842.

Palkovicova, Z., Knizatova, M., Mihina, S., Broucek, J., Hanus, A., 2009. Emissions of greenhouse gases and ammonia from intensive pig breeding. Folia Vet. 53, $168-170$.

Pedersen, S., Blanes-Vidal, V., Jørgensen, H., Chwalibog, A., Haeussermann, A., Heetkamp, M., Aarnink, A., 2008. Carbon dioxide production in animal houses: a literature review. Manuscript BC 08008.

Pelletier, N., Lammers, P., Stender, D., Pirog, R., 2010. Life cycle assessment of highand low-profitability commodity and deep-bedded niche swine production systems in the Upper Midwestern United States. Agric. Syst. 103, 599-608.

Pepple, L., Burns, R., Xin H., Li, H., Patience, J., 2011. Ammonia, hydrogen sulfide, and greenhouse gas emissions from wean-to-finish swine barns fed diets with or without DDGS. Agric. Biosyst. Eng. Conference Papers, Posters and Presentations. Paper 138.

Petersen, S.O., Miller, D.N., 2006. Greenhouse gas mitigation by covers on livestock slurry tanks and lagoons. J. Sci. Food Agric. 86, 1407-1411.

Philippe, F.X., Cabaraux, J.F., Laitat, M., Stilmant, D., Wavreille, J., Nicks, B., 2013. Les Impacts Environnementaux Du Choix Des Modalités D'hébergement Des Porcs Charcutiers. University of Liège, Liège, Belgium, and Walloon Agricultural Research Centre, Gembloux, Belgium.

Philippe, F.X., Cabaraux, J.F., Nicks, B., 2011a. Ammonia emissions from pig houses: influencing factors and mitigation techniques. Agric. Ecosyst. Environ. 141, 245260.

Philippe, F.X., Canart, B., Laitat, M., Wavreille, J., Bartiaux-Thill, N., Nicks, B., Cabaraux, J.F., 2010. Effects of available surface on gaseous emissions from group-housed gestating sows kept on deep litter. Animal 4, 1716-1724.

Philippe, F.X., Canart, B., Laitat, M., Wavreille, J., Vandenheede, M., Bartiaux-Thill, N., Nicks, B., Cabaraux, J.F., 2009. Gaseous emissions from group-housed gestating sows kept on deep litter and offered an ad libitum high-fibre diet. Agric. Ecosyst. Environ. 132, 66-73.

Philippe, F.X., Laitat, M., Canart, B., Farnir, F., Massart, L., Vandenheede, M., Nicks, B., 2006a. Effects of a reduction of diet crude protein content on gaseous emissions from deep-litter pens for fattening pigs. Anim. Res. 55, 397-407.

Philippe, F.X., Laitat, M., Canart, B., Vandenheede, M., Nicks, B., 2007a. Comparison of ammonia and greenhouse gas emissions during the fattening of pigs: kept either on fully slatted floor or on deep litter. Livestock Sci. 111, $144-152$.

Philippe, F.X., Laitat, M., Canart, B., Vandenheede, M., Nicks, B., 2007b. Gaseous emissions during the fattening of pigs kept either on fully slatted floors or on straw flow. Animal 1, 1515-1523.

Philippe, F.X., Laitat, M., Nicks, B., Cabaraux, J.F., 2012a. Ammonia and greenhouse gas emissions during the fattening of pigs kept on two types of straw floor. Agric. Ecosyst. Environ. 150, 45-53.

Philippe, F.X., Laitat, M., Vandenheede, M., Canart, B., Nicks, B., 2006b. Comparison of zootechnical performances and nitrogen contents of effluent for fattening pigs kept either on slatted floor or on straw-based deep litter. Ann. Méd. Vét. 150, 137-144.

Philippe, F.X., Laitat, M., Wavreille, J., Bartiaux-Thill, N., Nicks, B., Cabaraux, J.F., 2011b. Ammonia and greenhouse gas emission from group-housed gestating sows depends on floor type. Agric. Ecosyst. Environ. 140, 498-505.

Philippe, F.X., Laitat, M., Wavreille, J., Bartiaux-Thill, N., Nicks, B., Cabaraux, J.F., 2012b. Effets des fibres et du type de sol sur les émissions de gaz à effet de serre et d'ammoniac associées à l'élevage de truies. Journées Rech. Porcine 44, 133-134.

Philippe, F.X. Laitat, M., Wavreille, J., Nicks, B., Cabaraux, J.F., 2014a. Ammonia and greenhouse gases emissions associated to fattening pigs kept either on fully or partly slatted floor. Journées Rech. Porcine 46, 211-212.

Philippe, F.X., Laitat, M., Wavreille, J., Nicks, B., Cabaraux, J.F., 2014b. Effects of the amount of straw on ammonia and greenhouse gases emissions associated to fattening pigs kept on deep litter. Journées Rech. Porcine 46, 213-214.

Philippe, F.X., Remience, V., Dourmad, J.Y., Cabaraux, J.F., Vandenheede, M., Nicks, B., 2008. Food fibers in gestating sows: effects on nutrition behaviour, performances and waste in the environment. INRA Prod. Anim. 21, 277-290.

Pineiro, C., Montalvo, G., Garcia, M.A., Bigeriego, M., 2009. Influence of Soya Bean Meal and Synthetics Amino Acids Prices in the Cost of Nutritional Best Available Techniques in Spain. In: Book of Abstracts of the 60th Annual Meeting of the European Association for Animal Production. Wageningen Academic Publishers, Wageningen, The Netherlands p. 327.

Poth, M., Focht, D.D., 1985. N-15 kinetic-analysis of $\mathrm{N}_{2} \mathrm{O}$ production by nitrosomonas-europaea - an examination of nitrifier denitrification. Appl. Environ. Microbiol. 49, 1134-1141.

Quiniou, N., Dubois, S., Noblet, J., 1995. Effect of dietary crude protein level on protein and energy balances in growing pigs: comparison of two measurement methods. Livestock Prod. Sci. 41, 51-61.

Ramonet, Y., van Milgen, J., Dourmad, J.Y., Dubois, S., Meunier-Salaun, M.C., Noblet, J., 2000. The effect of dietary fibre on energy utilisation and partitioning of heat production over pregnancy in sows. Brit. J. Nutr. 84, 85-94.

Rigolot, C., Espagnol, S., Robin, P., Hassouna, M., Beline, F., Paillat, J.M., Dourmad, J.Y., 2010. Modelling of manure production by pigs and $\mathrm{NH}_{3} \mathrm{~N}_{2} \mathrm{O}$ and $\mathrm{CH}_{4}$ emissions. Part II: effect of animal housing, manure storage and treatment practices. Animal 4, 1413-1424.

Robin, P., de Oliveira, P.A., Kermarrec, C., 1999. Ammonia: nitrous oxide and water emissions from pigs housed on several types of litter during the growing period. Journées Rech. Porcine 31, 111-115.

Rodhe, L.K.K., Abubaker, J., Ascue, J., Pell, M., Nordberg, T., 2012. Greenhouse gas emissions from pig slurry during storage and after field application in northern European conditions. Biosyst. Eng. 113, 379-394.

Schrama, J.W., Bosch, M.W., Verstegen, M.W.A., Vorselaars, A., Haaksma, J., Heetkamp, M.J.W., 1998. The energetic value of nonstarch polysaccharides in relation to physical activity in group-housed, growing pigs. J. Anim. Sci. 76, 3016-3023.

Serena, A., Jorgensen, H., Bach Knudsen, K.E., 2008. Digestion of carbohydrates and utilization of energy in sows fed diets with contrasting levels and physicochemical properties of dietary fiber. J. Anim. Sci. 86, 2208-2216.

Shah, S.B., Kolar, P., 2012. Evaluation of additive for reducing gaseous emissions from swine waste. Agric. Eng. Int.: CIGR J. 14, 10-20.

Sommer, S.G., 2001. Effect of composting on nutrient loss and nitrogen availability of cattle deep litter. Eur. J. Agron. 14, 123-133.

Sommer, S.G., Moller, H.B., 2000. Emission of greenhouse gases during composting of deep litter from pig production - effect of straw content. J. Agric. Sci. 134, 327-335.

Sommer, S.G., Petersen, S.O., Moller, H.B., 2004. Algorithms for calculating methane and nitrous oxide emissions from manure management. Nutr. Cycling Agroecosyst. 69, 143-154.

Sommer, S.G., Petersen, S.O., Sorensen, P., Poulsen, H.D., Moller, H.B., 2007. Methane and carbon dioxide emissions and nitrogen turnover during liquid manure storage. Nutr. Cycling Agroecosyst. 78, 27-36.

Stanier, R.Y., Ingraham, J.L., Wheelis, M.L., Painter, P.R., 1986. The Microbial World, fifth ed. Prentice-Hall, New Jersey.

Steinfeld, H., Gerber, P., Wassenaar, T., Castel, V., Rosales, C., de Haan, C., 2006. Livestock's Long Shadow: Environmental Issues and Options. Food and Agriculture Organization of the United Nations, Rome, Italy.

Stinn, J.P., Xin H., Li, H., Shepherd, T., Burns, R., 2011. Quantification of greenhouse gas and ammonia emissions from a Midwestern swine breeding/gestation/ farrowing facility. Agric. Biosyst. Eng. Conference Papers, Posters and Presentations. Paper 203.

Sun, G., Guo, H.Q., Peterson, J., Predicala, B., Lague, C., 2008. Diurnal odor, ammonia, hydrogen sulfide, and carbon dioxide emission profiles of confined swine grower/finisher rooms. J. Air Waste Manage. Assoc. 58, 1434-1448.

Szanto, G.L., Hamelers, H.M., Rulkens, W.H., Veeken, A.H.M., 2007. $\mathrm{NH}_{3}: \mathrm{N}_{2} \mathrm{O}$ and $\mathrm{CH}_{4}$ emissions during passively aerated composting of straw-rich pig manure. Bioresour. Technol. 98, 2659-2670.

Tsukahara, T., Azuma, Y., Ushida, K., 2001. The effect of a mixture of live lactic acid bacteria on intestinal gas production in pigs. Microb. Ecol. Health D 13, 105-110.

Van Milgen, J., Noblet, J., Dubois, S., Bernier, J.F., 1997. Dynamic aspects of oxygen consumption and carbon dioxide production in swine. Br. J. Nutr. 78, 397-410.

Van der Zaag, A.C., Gordon, R.J., Glass, V.M., Jamieson, R.C., 2008. Floating cover to reduce gas emissions from liquid manure storage: a review. Appl. Eng. Agric. 24, 657-671.

van 't Klooster, C., Heitlager, B., 1994. Determination of minimum ventilation rate in pig houses with natural ventilation based on carbon dioxide balance. J. Agric. Eng. Res. 57, 279-287. 
Vedrenne, F., Béline, F., Dabert, P., Bernet, N., 2008. The effect of incubation conditions on the laboratory measurement of the methane producing capacity of livestock wastes. Bioresour. Technol. 99, 146-155.

Velthof, G.L., Nelemans, J.A., Oenema, O., Kuikman, P.I., 2005. Gaseous nitrogen and carbon losses from pig manure derived from different diets. J. Environ. Qual. 34 698-706.

Vergé, X.P.C., Dyer, J.A., Desjardins, R.L., Worth, D., 2009. Greenhouse gas emissions from the Canadian pork industry. Livestock Sci. 121, 92-101.

Vermorel, M., Jouany, J.P., Eugène, M., Sauvant, D., Noblet, J., Dourmad, J.Y., 2008. Evaluation quantitative des émissions de méthane entérique par les animaux d'élevage en 2007 en France. INRA Prod. Anim. 21, 403-418.

Wang, J., Zhu, Y., Li, D., Jørgensen, H., Jensen, B., 2004. The influence of different fiber and starch types on nutrient balance and energy metabolism in growing pigs. Asian-Aust. J. Anim. Sci. 17, 263-270.
Weiss, F., Leip, A., 2012. Greenhouse gas emissions from the EU livestock sector: A life cycle assessment carried out with the CAPRI model. Agric. Ecosyst. Environ. 149, 124-134.

Wolter, M., Prayitno, S., Schuchardt, F., 2004. Greenhouse gas emission during storage of pig manure on a pilot scale. Bioresour. Technol. 95, 235-244.

Yamulki, S., 2006. Effect of straw addition on nitrous oxide and methane emissions from stored farmyard manures. Agric. Ecosyst. Environ. 112, 140-145.

Ye, Z., Zhang, G., Seo, I.H., Kai, P., Saha, C.K., Wang, C., Li, B., 2009. Airflow characteristics at the surface of manure in a storage pit affected by ventilation rate floor slat opening, and headspace height. Biosyst. Eng. 104, 97-105.

Zhang, Q., Zhou, X.J., Cicek, N., Tenuta, M., 2007. Measurement of odour and greenhouse gas emissions in two swine farrowing operations. Can. Biosyst. Eng. 49, 6.13-6.20. 